\title{
Temporal variation of VOC fluxes measured with PTR-TOF above a boreal forest
}

\author{
Simon Schallhart ${ }^{1}$, Pekka Rantala ${ }^{1}$, Maija K. Kajos ${ }^{1}$, Juho Aalto ${ }^{2}$, Ivan Mammarella ${ }^{1}$, Taina M. Ruuskanen ${ }^{1}$, and \\ Markku Kulmala ${ }^{1}$ \\ ${ }^{1}$ Department of Physics, University of Helsinki, Helsinki, Finland \\ ${ }^{2}$ Department of Forest sciences, University of Helsinki, Helsinki, Finland
}

Correspondence: Simon Schallhart (simon.schallhart@helsinki.fi)

Received: 28 April 2017 - Discussion started: 1 June 2017

Revised: 20 October 2017 - Accepted: 1 December 2017 - Published: 23 January 2018

\begin{abstract}
Between April and June 2013 fluxes of volatile organic compounds (VOCs) were measured in a Scots pine and Norway spruce forest using the eddy covariance (EC) method with a proton transfer reaction time-of-flight (PTRTOF) mass spectrometer. The observations were performed above a boreal forest at the SMEAR II site in southern Finland.

We found a total of 25 different compounds with exchange and investigated their seasonal variations from spring to summer. The majority of the net VOC flux was comprised of methanol, monoterpenes, acetone and butene + butanol. The butene + butanol emissions were concluded to not originate from the forest and, therefore, be anthropogenic. The VOC exchange followed a seasonal trend and the emissions increased from spring to summer. Only three compounds were emitted during the snowmelt while in summer emissions of some 19 VOCs were observed. During the measurement period in April, the emissions were dominated by butene + butanol, while during the start of the growing season and in summer, methanol was the most emitted compound. The main source of methanol was likely the growth of new biomass. During a 21-day period in June, the net VOC flux was $2.1 \mathrm{nmol} \mathrm{m}^{-2} \mathrm{~s}^{-1}$. This is on the lower end of PTRTOF flux measurements from other ecosystems, which range from 2 to $10 \mathrm{nmol} \mathrm{m}^{-2} \mathrm{~s}^{-1}$. The EC flux results were compared with surface layer profile measurements, using a proton transfer reaction quadrupole mass spectrometer, which is permanently installed at the SMEAR II site. For the major compounds, the fluxes measured with the two different methods agreed well.
\end{abstract}

\section{Introduction}

Boreal forests, covering approximately $12.2 \times 10^{6} \mathrm{~km}^{2}$ of the earth's surface, which is $30 \%$ of the world's forest area (Keenan et al., 2015), emit volatile organic compounds (VOCs), which have an important impact on the chemistry and composition of the atmosphere. These emitted compounds can react with $\mathrm{O}_{3}, \mathrm{NO}_{3}$ or $\mathrm{OH}$ and form a multitude of new VOCs, which can contribute to the formation and growth of aerosol particles and thereby affect climate change (Tunved et al., 2006; Spracklen et al., 2008). An understanding of these emissions and their quantity is necessary for numerical assessments of future climate and air quality (Guenther et al., 2012; Makkonen et al., 2012). The direct measurement of VOC fluxes above the canopy is one key element in this process. Eddy covariance (EC) has become a reference method for measuring canopy exchange (Baldocchi, 2014).

The ecosystem-scale VOC fluxes result from emissions caused by biological activity and chemistry which take place in soil, forest floor and understory vegetation, trees and within the canopy airspace. The prevalent ability to synthesize and release VOCs to the atmosphere varies between species and often changes with seasons and during the life cycle of a plant (Karl et al., 2003; Hakola et al., 2006; Holzke et al., 2006). The more heterogeneous a habitat, the more potential sources of variation as regards VOC fluxes exist. Although managed boreal forests are commonly considered to be relatively homogeneous habitats, they are still relatively heterogeneous when compared to grasslands or other agricultural areas (Newbold et al., 2015). In addition to the array of tree species, the understory and forest floor vegeta- 
tion vary significantly in terms of species selection, luxuriance and coverage as a result of soil properties, orientation, canopy coverage and water availability. Even a single species, as exemplified by Scots pine, may express considerable intra-species variation in terms of emission composition (Bäck et al., 2012) and capacity (Aalto et al., 2014, 2015). Soils and forest floors are very complex but as yet poorly understood sources of VOCs (Aaltonen et al., 2011, 2013); however, the diverse forms of microbial activity seem to play a central role in VOC emissions from the soil (Bäck et al., 2010). In this context, above-canopy VOC flux measurements represent a vast array of signals from biogenic activity, which largely complicates drawing conclusions on the effects of biological and ecophysiological phenomena on VOC emissions from forests. However, the above-canopy VOC flux method is a crucial tool in studying VOC emission in a continuum from the subcellular scale up to the effects of VOCs on atmospheric composition and processes on local, regional and global scales.

VOC concentrations and emissions have been measured during campaigns since 1998 at SMEAR II (Station for Measuring Ecosystem-Atmosphere Relations). The VOC flux measurements at the station have consisted of different instruments and techniques: disjunct eddy covariance (DEC; e.g., Rinne et al., 2007), the surface layer profile (SLP) method (e.g., Rantala et al., 2014) using a proton transfer reaction quadrupole (PTR-Quad) mass spectrometer and a gas chromatograph mass spectrometer using the gradient method (e.g., Rinne et al., 2000). In recent years, proton transfer reaction time-of-flight (PTR-TOF) mass spectrometers have been used to measure EC fluxes (Ruuskanen et al., 2011; Kaser et al., 2013a; Park et al., 2013; Brilli et al., 2016; Schallhart et al., 2016), but the number of these studies is still low. With this new measurement setup, it is possible to identify the elemental composition of the compounds with detectable fluxes. Furthermore, the preselection of the measured compounds is no longer necessary, as the PTR-TOF measures full mass spectra. Its ability to measure all VOCs with $10 \mathrm{~Hz}$ time resolution leads to noise reduction compared to the DEC method using PTR-Quad, which uses a lower measurement frequency (typically 0.05 to $1 \mathrm{~Hz}$; e.g., Rinne and Amman, 2012).

This study used a PTR-TOF to measure VOC fluxes during the snowmelt (9 days), start of the growing season ( 9 days) and summer (21 days) 2013 and these are the first results from EC measurements of VOCs above a boreal forest. The main objective was to investigate how the set of compounds with detectable fluxes and their flux magnitude change during the transition from winter to summer. A second objective was to compare these PTR-TOF EC measurements with the long-term PTR-Quad measurements of SLP fluxes. Finally, the results from the 21 days of flux measurements in June were compared with other VOC flux studies using EC and PTR-TOF.

\section{Methods}

\subsection{Site description}

The measurements were carried out from April until the end of June 2013 at SMEAR II in Hyytiälä, southern Finland. The station is $180 \mathrm{~m}$ above sea level and located in the middle of a Pinus sylvestris (Scots pine) dominated stand, while Picea abies (Norway spruce) covers $15 \%$ of the forest. In addition to the dominating Scots pine and Norway spruce, other tree species are present at the study site, e.g., Betula pendula and Betula pubescens (silver and downy birch), Рориlus tremula (trembling aspen), Sorbus aucuparia (rowan) and Salix caprea (goat willow). The forest was planted in 1962, and since then the trees have grown to $18 \mathrm{~m}$ height and the stand density is approximately $1300 \mathrm{ha}^{-1}$. Depending on the season, the leaf area index varies between 2 and 2.5 (Rautiainen et al., 2012). More information about the surroundings of the station can be found in Hari and Kulmala (2005) and Ilvesniemi et al. (2010). The mean annual temperature was $3.5^{\circ} \mathrm{C}$ and the mean annual precipitation was $711 \mathrm{~mm}$ during the climatological normal period 1981-2010 (Pirinen et al., 2012). The measurements were conducted on a scaffold tower $\left(61.847407^{\circ} \mathrm{N}, 24.295150^{\circ} \mathrm{E}\right)$ and the inlet height was $23 \mathrm{~m}$. The temperature varied between -2 and $27^{\circ} \mathrm{C}$ during the measurement periods and the main wind direction was south-southwest.

\subsection{Flux measurement setup}

The measurements were conducted with a PTR-TOF 8000 (Ionicon Analytic GmbH; Jordan et al., 2009; Graus et al., 2010). It was operated with a drift tube voltage of $600 \mathrm{~V}$ and a drift tube pressure of 2.3 mbar. Together with the drift tube temperature of $60^{\circ} \mathrm{C}$, the $E_{\mathrm{PTR}} / N_{\mathrm{PTR}}\left(E_{\mathrm{PTR}}\right.$ being the electrical field strength and $N_{\text {PTR }}$ the gas number density) was calculated to be $130 \mathrm{Td}$. The instrument was placed in an airconditioned cottage next to the measurement tower. Sample air was pumped through a $30 \mathrm{~m}$ long $(8 \mathrm{~mm}$ inner diameter, i.d.) PTFE inlet, with a flow of $20 \mathrm{~L} \mathrm{~min}^{-1}$. To prevent condensation on the inlet walls, the tube was heated with an $8 \mathrm{~W} \mathrm{~m}^{-1}$ passive heating wire. A subsample of $0.5 \mathrm{~L} \mathrm{~min}^{-1}$ was collected via a $10 \mathrm{~cm}$ PTFE tubing (1.6 mm i.d.), which led over a three-way valve (type 6606 with ETFE, Bürkert $\mathrm{GmbH} \& \mathrm{Co} . \mathrm{KG})$ and $20 \mathrm{~cm}$ of PEEK tubing ( $1 \mathrm{~mm}$ i.d.) to the PTR-TOF. The PTR-TOF data were analyzed with the tofTools, which are described in more detail in Junninen et al. (2010). A 3-D ultrasonic anemometer (HS-1199, Gill instruments) was placed $10 \mathrm{~cm}$ above the inlet. Both VOC and wind measurements were recorded at $10 \mathrm{~Hz}$ resolution. In addition, EC fluxes of carbon dioxide $\left(\mathrm{CO}_{2}\right)$ are routinely measured at the site using a closed-path infrared gas analyzer (Licor 6262, USA; Mammarella et al., 2009). $\mathrm{CO}_{2}$ fluxes were calculated by using EddyUH software (Mammarella et al., 2016). 
The instrumental background of the PTR-TOF was measured by guiding ambient air through a catalytic converter, which removed the VOCs. This VOC-free air was measured three times a day, starting at 00:02, 08:02 and 17:02, and each measurement session lasted for $25 \mathrm{~min}$. This led to a reduced amount of flux data during these hours. Switching between ambient air and the VOC-free air was done with a three-way valve (type: 6606 with ETFE, Bürkert GmbH \& Co. KG) controlled by the PTR-Manager (Ionicon Analytic GmbH).

For calibration this VOC-free air was mixed with a calibration gas (Apel Riemer Environmental Inc.) containing 16 different compounds. For uncalibrated compounds the sensitivities were categorized into three groups $\mathrm{C}_{x} \mathrm{H}_{y}$ (calculated from isoprene, benzene, toluene, $o$-xylene, trimethylbenzene, naphthalene, $\alpha$-pinene combined with $\mathrm{C}_{6} \mathrm{H}_{9}$ fragment), $\mathrm{C}_{x} \mathrm{H}_{y} \mathrm{O}_{z}$ (based on acetaldehyde, acrolein, acetone, 2-butanone) and $\mathrm{C}_{x} \mathrm{H}_{y} \mathrm{~N}_{z}$ (set to acetonitrile) similar to the setup Schallhart et al. (2016). The average sensitivities for the different compound groups were $11.4 \pm 2.5 \mathrm{ncps} \mathrm{ppb}^{-1}$ for $\mathrm{C}_{x} \mathrm{H}_{y}, 18.6 \pm 3.1 \mathrm{ncps} \mathrm{ppb}^{-1}$ for $\mathrm{C}_{x} \mathrm{H}_{y} \mathrm{O}_{z}$ and $17.7 \pm 2.0 \mathrm{ncps} \mathrm{ppb}^{-1}$ for $\mathrm{C}_{x} \mathrm{H}_{y} \mathrm{~N}_{z}$. Overall the sensitivities are comparable with Schallhart et al. (2016); only the standard deviation increased due to the longer time period of the measurements. The setup for background and calibration measurements is described in more detail in Schallhart et al. (2016).

\subsection{Flux and lag time calculations}

VOC fluxes were derived using the EC method (e.g., Aubinet et al., 2012). The EC flux is calculated using the covariance

$\overline{w^{\prime} c^{\prime}}(\lambda)=\frac{1}{n} \sum_{i=1}^{n} w^{\prime}(i-\lambda / \Delta t) c^{\prime}(i)$,

where $w^{\prime}$ and $c^{\prime}$ are high-frequency fluctuations of vertical wind and concentration, respectively, $i$ is the number of the measurement, $n$ the sum of all measurements during the flux averaging time (30 min in this study; $n=18000), \Delta t$ the sampling interval $(0.1 \mathrm{~s})$ and $\lambda$ the lag time caused by the sampling system. The cross-covariance functions (CCFs) were calculated by varying $\lambda$ from -200 to $200 \mathrm{~s}$. In this study, vertical wind and VOC concentrations were both recorded at $10 \mathrm{~Hz}$ frequency. The flux calculation procedure is called the automated method and is similar to that in Park et al. (2013) and Schallhart et al. (2016); only the lag time was determined differently.

The VOC and the wind data were recorded on two different computers and their clocks shifted considerably (continuous shift of 2 to $5 \mathrm{~s} \mathrm{day}^{-1}$; Fig. 1a). Finding the correct lag time is especially challenging when the flux is close to the detection limit. To estimate the proper lag times, three corrections were made.

First, the artificial clock shifting was removed using linear regressions. Therefore, the regressions from the monoterpene
CCFs were used to correct the CCFs from all compounds (Fig. 1b).

In the second step, an average, absolute CCF was calculated (Fig. 2) for each compound. For this the absolute value of each $30 \mathrm{~min}$ CCF between 10:00 and 16:00 was taken and then all the absolute CCFs for the time period of interest were averaged. To reduce the influence of noise, especially when small fluxes are measured, a running mean $( \pm 24-$ step averaging) was used. Then the position of the maximum was searched for a $\pm 10 \mathrm{~s}$ time window and used as the lag time. This step corrects possible differences in the average lag time between the compound of interest and the monoterpenes. This lag time was calculated for each month and each compound separately.

The third and last step was used to correct for smaller shifts, in case the first correction, with the linear regression, was not precise enough. Therefore, each individual $30 \mathrm{~min}$ CCF was smoothed by a running mean $( \pm 24$-step averaging) and the location of the maximum in a $\pm 10 \mathrm{~s}$ time window around the previously calculated lag time was recorded (Taipale et al., 2010), as shown for the monoterpenes in Fig. 1c.

To classify how many of the hundreds of measured compounds show an exchange, a method described in Park et al. (2013) and Schallhart et al. (2016) was used. This method compares the maximum of the averaged, absolute CCF with a certain noise threshold. To reduce the impact of noise, the averaged, absolute CCF was smoothed ( \pm 12 -step averaging) and the location of the maximum in a $\pm 10 \mathrm{~s}$ time window detected. This position was used in the average, absolute CCF (not smoothed) and compared with the $\sigma_{\text {noise }}$ (standard deviation of the noise). The $\sigma_{\text {noise }}$ was calculated for $60 \mathrm{~s}$ at the borders of the average absolute $\mathrm{CCF}$. If the ratio between the calculated maximum and the $\sigma_{\text {noise }}$ was higher than three, the compound was classified to have detectable flux (Fig. 2). This method was applied to flux determinations for each month separately.

The flux underestimation caused by high-frequency attenuation was estimated using a parametrization described by Horst (1997). The method uses a system response time and information about stability and horizontal wind speed for estimating the attenuation. The system response time was determined to be around $1.2 \mathrm{~s}$ for monoterpenes and the same response time was also used for all the other compounds. One should note that the determined response time describes the flux attenuation of the whole measurement setup, including the tubing, a horizontal separation between the inlet and the anemometer and the instrument itself. In this case, the average attenuation factor was $18 \%$. On average, the correction factor was smaller during the day $(16 \% ; 09: 00$ to 17:00) and larger at night (23\%; 20:00 to 04:00).

No additional corrections were applied to the measured fluxes (e.g., storage correction). 

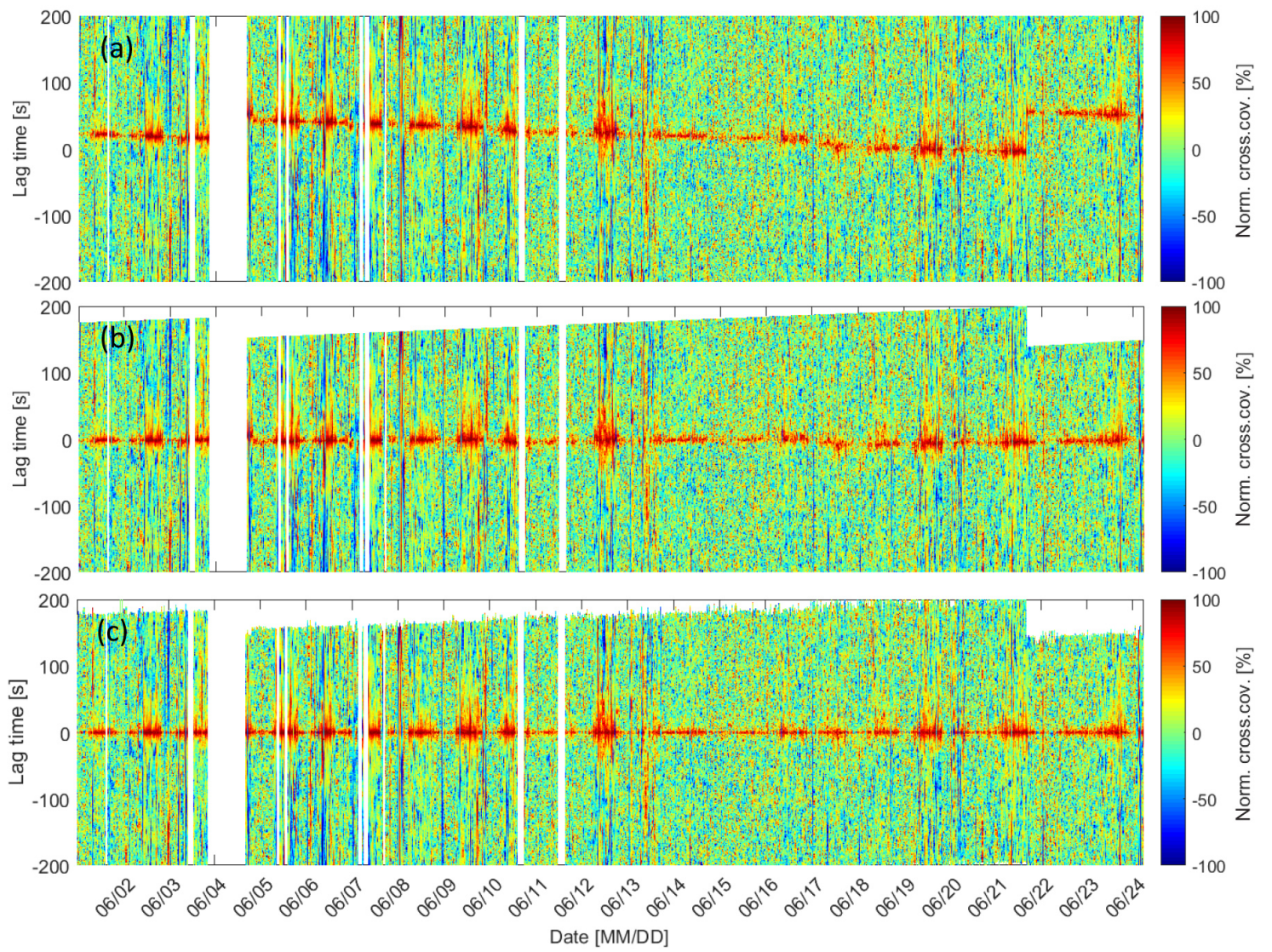

Figure 1. (a) Normalized cross-covariance functions (CCFs) for monoterpene measurements in June, without time shift correction. The shift between the two computer clocks is clearly visible. (b) CCFs after correcting for lag time shifts. (c) The CCFs of monoterpenes after the final lag time correction. In the final (third) step, the smoothed maximum of the CCF function (see Fig. 2) was sought for each compound and 30 min data individually, in a $\pm 10 \mathrm{~s}$ window of the previous lag time (step 1 and 2 ).

\subsection{Flux quality criteria}

The measured fluxes were filtered by three quality criteria, to reduce the systematic uncertainty and ensure their representativeness.

First, the data were flagged if the tilt angle, resulting from the coordinate rotation of sonic anemometer wind velocity components (Kaimal and Finnigan, 1994), was more than $5^{\circ}$, which was the case for $11.9 \%$ of the data. Second, all $30 \mathrm{~min}$ records with a friction velocity less than $0.2 \mathrm{~m} \mathrm{~s}^{-1}$ were flagged. Following this, $11.2 \%$ of the data were flagged. Finally, the flux steady-state test was applied according to Foken and Wichura (1996). All flagged flux values were removed from further analysis. The rejection rate between April and June was 34.1, 35.1 and $30.5 \%$ for acetone, butene + butanol, and the monoterpenes, respectively. For the monoterpenes, the rejection rates for the measurement periods in April, May and June were 19.1, 17.6 and $30 \%$ (daytime) and 25.6, 24.0 and $43.7 \%$ (nighttime), respectively.

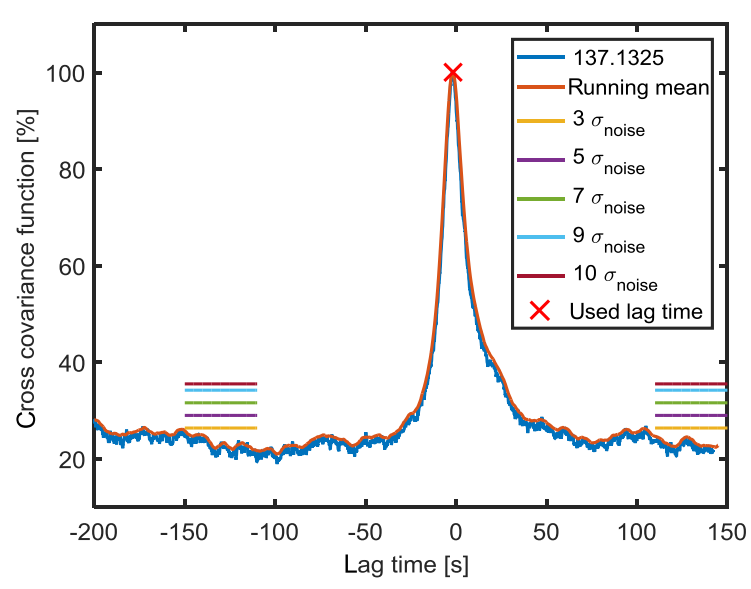

Figure 2. For each compound which had a maximum above $3 \sigma_{\text {noise, }}$, the deviation of the CCF maxima from zero was used as the lag time correction. 


\subsection{Flux selection}

The temporal behavior of the VOC exchange was investigated by measuring periods in April, May and June 2013. These periods give insight to the VOC exchange during snowmelt, the start of the growing season and summer. Because of technical problems with the anemometer, which stopped recording data on several occasions during the start of the growing season, only $423 \times 30$ min files ( $\sim 9$ days of data) of VOC fluxes could be calculated in the period from 4 to 24 May 2013. The standard deviation of noise in the averaged, absolute CCFs ( $\left.\sigma_{\text {noise }}\right)$ determines the exchange threshold and is directly dependent on the amount of data. Therefore, the same amount of data $(423 \times 30 \mathrm{~min}$ files $)$ was selected to represent each period from snowmelt to summer and make a comparison between those periods possible. For all three periods, the absolute mean of the CCFs between 10:00 and 16:00 (UTC + 2) was used to find compounds with statistically significant flux (Park et al., 2013; Schallhart et al., 2016). For the snowmelt, the measurements were from 14 to 24 April 2013 and for summer the hottest period was selected, from 1 to 12 June 2013.

\section{Results and discussion}

The PTR-TOF measures the mass of the VOCs in the ambient sample, which can be used to calculate the elemental composition. Therefore, no structural information of the measured molecules is known and the identification of compounds relies on literature and gas chromatograph measurements. Major masses affected by fragmentation and compounds with high uncertainties are discussed in the following.

The mass $69.0699 \mathrm{Da}$ with the elemental composition $\mathrm{C}_{5} \mathrm{H}_{9}^{+}$was called isoprene +2 -methyl-3-buten-2-ol (MBO), as MBO fragmented to this mass and had a substantial influence on the signal (e.g., Kaser et al., 2013b). Similarly, the mass 93.0699 Da with the elemental composition $\mathrm{C}_{7} \mathrm{H}_{9}^{+}$was called toluene $+p$-cymene, as $p$-cymene fragments were suspected to affect the signal (Tani et al., 2003). Formaldehyde has only a slightly higher proton affinity compared with the primary ion and therefore back reactions, which are humidity dependent, from protonated formaldehyde to water occur (de Gouw and Warneke, 2006; Inomata et al., 2008; Vlasenko et al., 2010). This may have led to an artificial flux, which was caused by water vapor fluctuations. Therefore, the formaldehyde fluxes are very uncertain. The signal at mass $57.0699 \mathrm{Da}$ with a protonated composition of $\mathrm{C}_{4} \mathrm{H}_{9}^{+}$was called butene + butanol, as butanol was suspected to have substantial influence on the signal (see Sect. 3.4). Furthermore, as the butene + butanol fluxes were expected to be caused by the aerosol instrumentation, they were disregarded in all reported net fluxes and total emissions. The monoterpenes $\left(\mathrm{C}_{10} \mathrm{H}_{17}^{+}\right)$were measured at mass $137.1325 \mathrm{Da}$ only. The monoterpene fragment at mass $81.0699 \mathrm{Da}\left(\mathrm{C}_{6} \mathrm{H}_{9}^{+}\right)$ was identified by its Pearson correlation of 0.99 (30 min integrated data) with the signal at $137.1325 \mathrm{Da}$ and was disregarded from further analysis.

\subsection{VOC flux variation during the campaign}

During the three 9-day measurement periods in April, May and June 22 compounds with a flux were found, of which 16 were identified by their elemental compositions (Table 1). Five compounds, $\mathrm{CH}_{3} \mathrm{O}^{+}$(formaldehyde), $\mathrm{CH}_{4} \mathrm{ON}^{+}$(formamide), $\mathrm{C}_{4} \mathrm{H}_{7} \mathrm{O}^{+}$(crotonaldehyde) and two unidentified peaks with the masses of 84.9500 and $118.9456 \mathrm{Da}$, had a negative net flux; each contributed around $1 \%$ or less to the total net flux (Fig. 3). As expected, the average net flux increased from snowmelt $\left(0.24 \mathrm{nmol} \mathrm{m}^{-2} \mathrm{~s}^{-1}\right)$ to the start of the growing season $\left(1.07 \mathrm{nmol} \mathrm{m}^{-2} \mathrm{~s}^{-1}\right)$ and summer $\left(2.75 \mathrm{nmol} \mathrm{m}^{-2} \mathrm{~s}^{-1}\right)$. The compounds with detectable fluxes increased from 3 during the snowmelt to 12 at the start of the growing season and 19 in summer. Over $75 \%$ of the net flux comprised of methanol, acetone and monoterpenes. Of those three main compounds, acetone and monoterpenes had similar emission patterns (based on the total net flux) over the measurement period, while methanol had no detectable flux in April. The development of the diurnal cycle can also be seen in Fig. 4, as the measurements in April had a minor flux variation between day and night, whereas the periods in May and June showed a clear dependence on the temperature. The maximum emission was detected between 14:00 and 16:00 (Fig. 4); this is in agreement with the fact that VOC synthesis is driven by temperature and light (Ghirardo et al., 2010; Taipale et al., 2011), while potential evaporation from storage pools is primarily driven by temperature alone (Guenther et al., 1993). The maximum temperatures were typically measured during mid-afternoon, when the light availability has still not yet decreased to a great extent when compared to the light conditions around noon. Figure 5 shows that the highest emissions of monoterpenes and isoprene $+\mathrm{MBO}$ coincided with the highest temperatures. Furthermore, the high monoterpene emissions during low photosynthetically active radiation (PAR) $\left(<200 \mu \mathrm{mol} \mathrm{m}^{-2} \mathrm{~s}^{-1}\right.$; gray data points in Fig. 5) conditions can be explained by pool emissions, whereas the de novo isoprene emissions during this time were low. Unlike the maximum emission time, which was similar for all months, the minimum net flux was between 20:00 and 21:00 during the snowmelt, 03:00 and 04:00 at the start of the growing season and 01:00 and 02:00 in summer. Table 1 shows all the compounds with detectable flux for the 3 months and their $24 \mathrm{~h}$ average emission and deposition.

\subsubsection{Low emissions during snowmelt}

As expected the total emission $\left(0.25 \mathrm{nmol} \mathrm{m}^{-2} \mathrm{~s}^{-1}\right)$ was smallest during the measurement period in April (compared to the start of the growing season and summer). The snow melted during this period and the average temperature and 
Table 1. The exchange of the different compounds in during the measurements in April, May and June. All the presented emission (E) and deposition $(D)$ values are in percentages in relation to the total emission or deposition of the month (stated in the last line). Emissions of butene + butanol are in bold as they are anthropogenic (Sect. 3.4) and, therefore, not included in the total exchange.

\begin{tabular}{|c|c|c|c|c|c|c|c|c|}
\hline \multirow[t]{2}{*}{$\begin{array}{l}\text { Mass } \\
(\mathrm{Da})\end{array}$} & \multirow[t]{2}{*}{$\begin{array}{l}\text { Elemental } \\
\text { composition }\end{array}$} & \multirow[t]{2}{*}{$\begin{array}{l}\text { Possible } \\
\text { compound }\end{array}$} & \multicolumn{2}{|c|}{ Snowmelt } & \multicolumn{2}{|c|}{$\begin{array}{l}\text { Start of growing } \\
\text { season }\end{array}$} & \multicolumn{2}{|c|}{ Summer } \\
\hline & & & $E$ & $D$ & E & $D$ & $E$ & $D$ \\
\hline 33.0335 & $\mathrm{CH}_{5} \mathrm{O}^{+}$ & methanol & & & 39.6 & $49.1^{*}$ & 42.1 & $16.5^{*}$ \\
\hline 137.1325 & $\mathrm{C}_{10} \mathrm{H}_{17}^{+}$ & monoterpenes & 47.7 & 0 & 26.0 & 0 & 21.0 & 0 \\
\hline 59.0491 & $\mathrm{C}_{3} \mathrm{H}_{7} \mathrm{O}^{+}$ & acetone & 52.3 & $100^{*}$ & 18.9 & 0 & 14.3 & $<1^{*}$ \\
\hline 57.0699 & $\mathrm{C}_{4} \mathrm{H}_{9}^{+}$ & butene + butanol & 170.5 & $\mathbf{0}$ & 12.1 & $\mathbf{0}$ & 8.9 & $\mathbf{0}$ \\
\hline 45.0335 & $\mathrm{C}_{2} \mathrm{H}_{5} \mathrm{O}^{+}$ & acetaldehyde & & & & & 5.5 & $4.0^{*}$ \\
\hline 69.0699 & $\mathrm{C}_{5} \mathrm{H}_{9}^{+}$ & isoprene $+\mathrm{MBO}$ & & & 2.4 & $<1^{*}$ & 4.6 & $1.2^{*}$ \\
\hline 61.0284 & $\mathrm{C}_{2} \mathrm{H}_{5} \mathrm{O}_{2}^{+}$ & acetic acid & & & & & 2.6 & $4.1^{*}$ \\
\hline 43.0178 & $\mathrm{C}_{2} \mathrm{H}_{3} \mathrm{O}^{+}$ & fragment & & & & & 2.4 & $7.7^{*}$ \\
\hline 41.0386 & $\mathrm{C}_{3} \mathrm{H}_{5}^{+}$ & fragment & & & 2.9 & $3.7^{*}$ & 2.5 & $<1^{*}$ \\
\hline 31.0178 & $\mathrm{CH}_{3} \mathrm{O}^{+}$ & formaldehyde & & & & & $<1$ & 41.4 \\
\hline 60.0471 & 60.0471 & unknown & & & 3.8 & $6.8^{*}$ & 1.3 & $9.0^{*}$ \\
\hline 93.0699 & $\mathrm{C}_{7} \mathrm{H}_{9}^{+}$ & toluene $+p$-cymene & & & 2.6 & $<1^{*}$ & $<1$ & 1.8 \\
\hline 69.0352 & 69.0352 & unknown & & & & & $<1$ & $<1^{*}$ \\
\hline 67.0542 & $\mathrm{C}_{5} \mathrm{H}_{7}^{+}$ & cyclopentadiene & & & & & $<1$ & $<1^{*}$ \\
\hline 70.0696 & 70.0696 & unknown & & & $<1$ & 2.6 & $<1$ & $1.7^{*}$ \\
\hline 99.0201 & 99.0201 & unknown & & & & & $<1$ & $3.6^{*}$ \\
\hline 84.9500 & 84.9500 & unknown & & & & & $<1^{*}$ & 4.8 \\
\hline 95.0491 & $\mathrm{C}_{6} \mathrm{H}_{7} \mathrm{O}^{+}$ & phenol & & & & & $<1$ & $1.1^{*}$ \\
\hline 135.1168 & $\mathrm{C}_{10} \mathrm{H}_{15}^{+}$ & $p$-cymene & & & & & $<1^{*}$ & $<1^{*}$ \\
\hline 46.0287 & $\mathrm{CH}_{4} \mathrm{ON}^{+}$ & formamide & & & 2.1 & 23.9 & & \\
\hline 118.9456 & 118.9456 & unknown & & & $<1^{*}$ & 9.0 & & \\
\hline 71.0491 & $\mathrm{C}_{4} \mathrm{H}_{7} \mathrm{O}^{+}$ & MVK and MACR & & & $<1$ & 7.9 & & \\
\hline \multicolumn{3}{|c|}{ Total emission and deposition $\left(\mathrm{nmol} \mathrm{m}^{-2} \mathrm{~s}^{-1}\right)$} & 0.25 & -0.01 & 1.24 & -0.17 & 2.87 & -0.12 \\
\hline
\end{tabular}

* Values under the limit of detection $\left(2 \sigma_{\text {ind }}\right) . \sigma_{\text {ind }}$ was calculated using the propagation of error formula and the standard deviation at the borders of the individual $30 \mathrm{~min}$ CCFs.

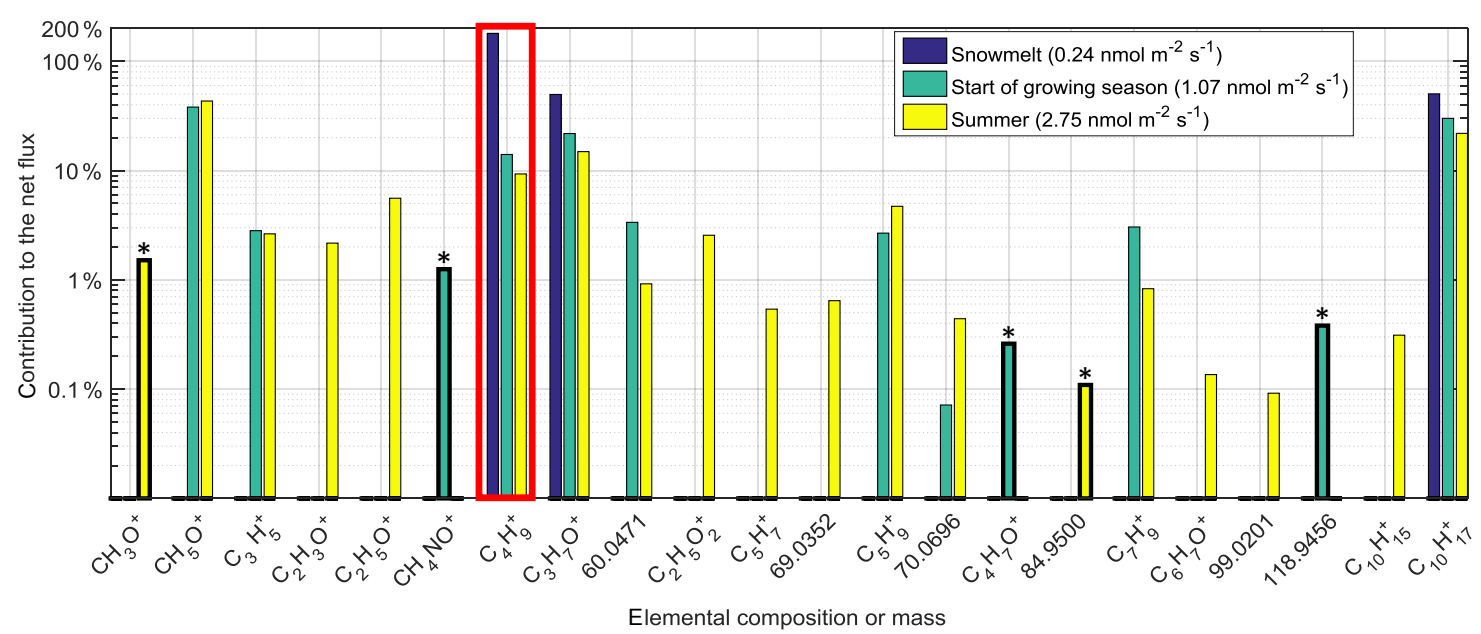

Figure 3. Contribution of each compound to the $24 \mathrm{~h}$ average net flux of the respective month. Bars with thick outlines and * above them correspond to negative fluxes, where the absolute value was taken before plotting them in the logarithmic scale. See Table 1 for corresponding compound names. Emissions of $\mathrm{C}_{4} \mathrm{H}_{9}^{+}$are highlighted with a red box as they are anthropogenic (Sect. 3.4) and, therefore, are not included in the net flux. 


\begin{tabular}{|c|c|c|c|}
\hline $\mathrm{CH}_{5} \mathrm{O}^{+}$methanol & $\mathrm{C}_{10} \mathrm{H}_{17}^{+}$monoterpenes & $\mathrm{C}_{3} \mathrm{H}_{7} \mathrm{O}^{+}$acetone & $\mathrm{C}_{2} \mathrm{H}_{5} \mathrm{O}^{+}$acetaldehyde \\
\hline $\mathrm{C}_{5} \mathrm{H}_{9}^{+}$isoprene \& $\mathrm{MBO}$ & $\mathrm{C}_{2} \mathrm{H}_{5} \mathrm{O}_{2}^{+}$acetic acid & $\mathrm{C}_{2} \mathrm{H}_{3} \mathrm{O}^{+}$fragment & fragment \\
\hline 60.0471 not identified & toluene \& p-cymene & $\mathrm{CH}_{4} \mathrm{NO}^{+}$formamide & Other \\
\hline $\mathrm{C}_{4} \mathrm{H}_{9}^{+}$butene \& butanol ${ }^{*}$ & & & \\
\hline
\end{tabular}
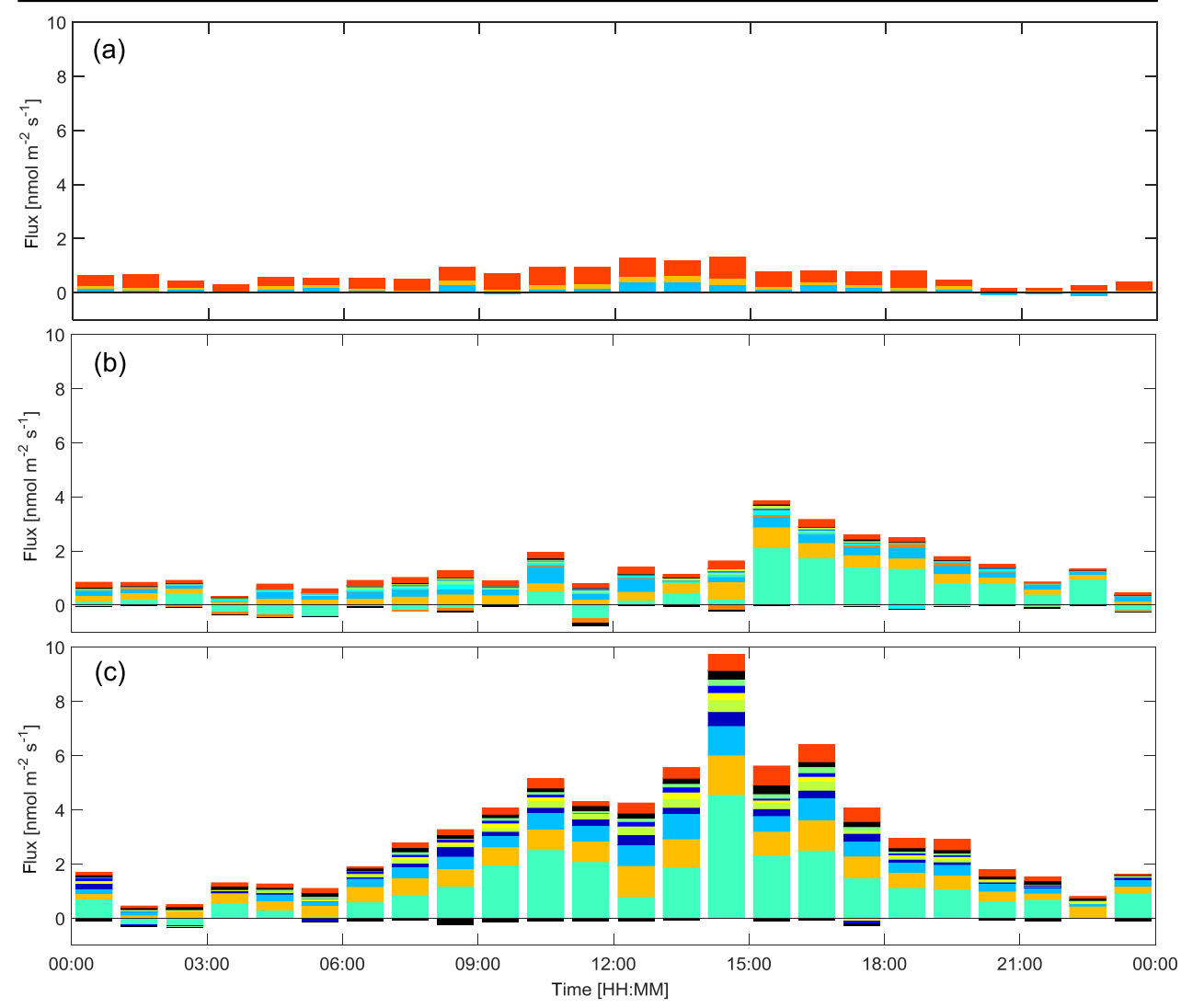

Figure 4. Diurnal pattern of the nine compounds with the highest fluxes, the remaining compounds being summed up as "other". The panels show the fluxes for snowmelt (a), start of growing season (b) and summer (c). The number of data points per hour is dependent on the quality criteria filtering and whether it is in an hour when the automatic background was measured. ${ }^{*}$ The butene + butanol exchange is anthropogenic and thereby not emitted by the forest (Sect. 3.4).

PAR were at their lowest, $4.4^{\circ} \mathrm{C}$ and $268 \mu \mathrm{mol} \mathrm{m}^{-2} \mathrm{~s}^{-1}$, respectively. The total deposition $\left(-0.01 \mathrm{nmol} \mathrm{m}^{-2} \mathrm{~s}^{-1}\right)$ was also weakest. Acetone contributed with over $50 \%$ to the emissions and was the only compound during the snowmelt for which a diurnal deposition was detected. Between 22:00 and 23:00 the measured flux reached a minimum of $-0.12 \mathrm{nmol} \mathrm{m}^{-2} \mathrm{~s}^{-1}$, whereas between 13:00 and 14:00 the emission peaked with $0.40 \mathrm{nmol} \mathrm{m}^{-2} \mathrm{~s}^{-1}$. The heaviest measured compounds with detectable flux were the group of monoterpenes, which contributed $48 \%$ to the total emission and had the highest emissions between 14:00 and $15: 00$ with $0.24 \mathrm{nmol} \mathrm{m}^{-2} \mathrm{~s}^{-1}$. The lowest emissions of $0.06 \mathrm{nmol} \mathrm{m}^{-2} \mathrm{~s}^{-1}$ were measured during morning between 06:00 and 07:00. The anthropogenic emissions of butene + butanol dominated by a factor of 1.7 over the biogenic emissions. $\mathrm{C}_{4} \mathrm{H}_{9}^{+}$had the highest emissions between
14:00 and 15:00 with $0.82 \mathrm{nmol} \mathrm{m}^{-2} \mathrm{~s}^{-1}$ and the lowest between 21:00 and 22:00 with $0.08 \mathrm{nmol} \mathrm{m}^{-2} \mathrm{~s}^{-1}$.

\subsubsection{Increase of emissions at start of growing season}

The total emission during the start of the growing season in May was $1.24 \mathrm{nmol} \mathrm{m}^{-2} \mathrm{~s}^{-1}$ and the total deposition was more than $10 \%$ of the emission, $-0.17 \mathrm{nmol} \mathrm{m}^{-2} \mathrm{~s}^{-1}$. The night temperatures during this period were above zero and the sun warmed late afternoons to around $20^{\circ} \mathrm{C}$. This led to a mean temperature of $11.4^{\circ} \mathrm{C}$ and the mean PAR was $301 \mu \mathrm{mol} \mathrm{m}{ }^{-2} \mathrm{~s}^{-1}$. Methanol dominated the emissions with $40 \%$ contribution to the total emission. The diurnal maximum of methanol occurred in the late afternoon at $2.11 \mathrm{nmol} \mathrm{m}^{-2} \mathrm{~s}^{-1}$. These results agree with other studies, which showed that methanol is released in plant growth (e.g., Galbally and Kirstine, 2002). In contrast, methanol showed also the highest deposition, comprising almost 


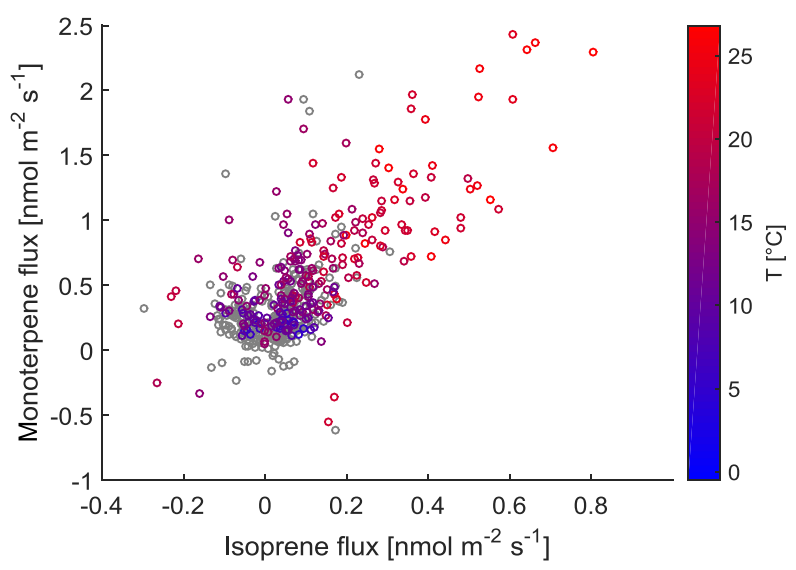

Figure 5. Scatterplot of $30 \mathrm{~min}$ isoprene and monoterpene flux. The gray data points are values where the PAR was smaller than $200 \mu \mathrm{mol} \mathrm{m}{ }^{-2} \mathrm{~s}^{-1}$. Isoprene fluxes are very low and especially during low PAR conditions they are heavily affected by noise and a mirroring effect (Langford et al., 2015).

$50 \%$ of the total deposition. The midday deposition of $-0.47 \mathrm{nmol} \mathrm{m}^{-2} \mathrm{~s}^{-1}$ between 11:00 and 12:00 can be explained by rain during or right before this time window, which happened twice during the measurements in the May period. The water-soluble methanol was suspected to be dry deposited on the wet surfaces in the forest (Laffineur et al., 2012; Wohlfahrt et al., 2015; Schallhart et al., 2016).

The monoterpenes were the second most emitted compound group and contributed $26 \%$ to the total emission. Their maximum emission was $0.76 \mathrm{nmol} \mathrm{m}^{-2} \mathrm{~s}^{-1}$ between 15:00 and 16:00 and the minimum emission was $0.13 \mathrm{nmol} \mathrm{m}^{-2} \mathrm{~s}^{-1}$ between 03:00 and 04:00. Recently, Aalto et al. $(2014,2015)$ have shown that Scots pine needles are a pronounced source of monoterpenes in spring already before growth onset, and especially after bud break, when the formation of new biomass releases large amounts of terpenoids and other VOCs. The results of this study are in general consistent with those findings in terms of detected mean fluxes and diurnal patterns. Acetone contributed with $19 \%$ to the total emission and was the third most emitted compound. It had the maximum emission of $0.61 \mathrm{nmol} \mathrm{m}^{-2} \mathrm{~s}^{-1}$ between 10:00 and 11:00 and the minimum between 03:00 and 04:00 with $0.04 \mathrm{nmol} \mathrm{m}^{-2} \mathrm{~s}^{-1}$. Formamide passed the $3 \sigma_{\text {noise }}$ criteria only in the May period, where it explained $2 \%$ of the total emission and $24 \%$ of the total deposition. The emissions were highest between 19:00 and 20:00 with $0.13 \mathrm{nmol} \mathrm{m}^{-2} \mathrm{~s}^{-1}$ and the deposition peaked between 12:00 and 13:00 with $-0.20 \mathrm{nmol} \mathrm{m}^{-2} \mathrm{~s}^{-1}$.

The emissions of butene + butanol, which is discussed in Sect. 3.4, were not related to the start of the growing season. The flux of $\mathrm{C}_{4} \mathrm{H}_{9}^{+}$decreased by almost twothirds compared to the snowmelt period and would increase the total emission by $11 \%$. The maximum flux of $0.29 \mathrm{nmol} \mathrm{m}^{-2} \mathrm{~s}^{-1}$ was between 15:00 and 16:00 and the minimum of $0.02 \mathrm{nmol} \mathrm{m}^{-2} \mathrm{~s}^{-1}$ between 22:00 and 23:00. However, during the start of the growing season, most of the emissions were biogenic.

\subsubsection{Maximum emissions during summer}

During the first weeks of June the highest average temperature and PAR were measured, with $17.2{ }^{\circ} \mathrm{C}$ and $466 \mu \mathrm{mol} \mathrm{m}^{-2} \mathrm{~s}^{-1}$, respectively. As temperature and light are the drivers of biogenic emissions (Guenther et al., 2012), the highest $24 \mathrm{~h}$ total emission of the campaign, $2.87 \mathrm{nmol} \mathrm{m}^{-2} \mathrm{~s}^{-1}$, was recorded during this time (Table 1). In Fig. 4 the maximum diurnal $1 \mathrm{~h}$ net flux is shown at 14:30 with $9.10 \mathrm{nmol} \mathrm{m}^{-2} \mathrm{~s}^{-1}$. Similar as in the period in May, methanol, the group of monoterpenes and acetone were the most emitted compounds and the emissions of the 10 most emitted compounds in summer all increased when compared to the measurement period in May (Table 1).

In the summer period methanol was the most emitted compound, comprising $42 \%$ of the total emission and $17 \%$ of the deposition. The methanol flux was highest between 15:00 and 16:00 with $4.56 \mathrm{nmol} \mathrm{m}^{-2} \mathrm{~s}^{-1}$, while between 03:00 and 04:00 it was deposited $\left(-0.26 \mathrm{nmol} \mathrm{m}^{-2} \mathrm{~s}^{-1}\right)$. Growing leaf biomass is expected to release methanol due to cell wall demethylation (Galbally and Kirstine, 2002; Hüve et al., 2007; Aalto et al., 2014). The increase of the $24 \mathrm{~h}$ methanol emissions from undetectable during the snowmelt to about $0.5 \mathrm{nmol} \mathrm{m}^{-2} \mathrm{~s}^{-1}$ during the start of the growing season and finally well above $1 \mathrm{nmol} \mathrm{m}^{-2} \mathrm{~s}^{-1}$ in summer coincides with the typical coniferous needle biomass growth onset at the beginning of May and maximum needle elongation rate around mid-summer (Aalto et al., 2014).

Other biogenic emissions include the group of monoterpenes contributing $21 \%$ and acetone contributing $14 \%$ to the total emission. Similar to methanol, the highest monoterpenes and acetone emissions were observed in the late afternoon, with 1.46 and $1.08 \mathrm{nmol} \mathrm{m}^{-2} \mathrm{~s}^{-1}$, respectively. Formaldehyde contributed over $40 \%$ to the total deposition in June, resulting in a flux minima of $-0.23 \mathrm{nmol} \mathrm{m}^{-2} \mathrm{~s}^{-1}$. However, formaldehyde flux measurements are uncertain, as discussed in Sect. 3. The anthropogenic flux of butene + butanol had a flux between 0.70 and $0.02 \mathrm{nmol} \mathrm{m}^{-2} \mathrm{~s}^{-1}$.

When we compared the selected 9 days to the 21 days in June (Fig. 6 and Table 2), we found that five compounds no longer fulfilled the $3 \sigma_{\text {noise }}$ criteria. Using the longer period lead to the rejection of formaldehyde, phenol, $p$-cymene and two unidentified masses 84.9500 and $99.0201 \mathrm{Da}$ (Tables 1 and 2). The rejection of formaldehyde was the major reason for the change of deposition from -0.12 to $-0.09 \mathrm{nmol} \mathrm{m}^{-2} \mathrm{~s}^{-1}$. Three new masses had a detectable flux, acetonitrile $(42.0338 \mathrm{Da})$ and two unidentified masses 89.0386 and $99.0769 \mathrm{Da}$. The total emission decreased from 2.87 to $2.16 \mathrm{nmol} \mathrm{m}^{-2} \mathrm{~s}^{-1}$. This difference can be explained 
Table 2. Comparison between different studies using a PTR-TOF with the EC method. The listed compounds are limited to the ones measured

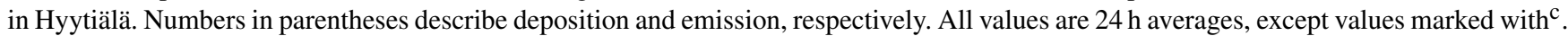
Emissions of butene + butanol are in bold as they are anthropogenic (Sect. 3.4) and, therefore, not included in the total exchange.

\begin{tabular}{|c|c|c|c|c|c|c|c|}
\hline \multicolumn{8}{|c|}{ Net flux (nmol m$\left.{ }^{-2} \mathrm{~s}^{-1}\right)$} \\
\hline $\begin{array}{l}\text { Mass } \\
(\mathrm{Da})\end{array}$ & $\begin{array}{l}\text { Elem. } \\
\text { comp. }\end{array}$ & $\begin{array}{r}\text { This study (21 } \\
\text { days June) }\end{array}$ & $\begin{array}{r}\text { Schallhart et } \\
\text { al. (2016) }\end{array}$ & $\begin{array}{r}\text { Park et } \\
\text { al. }(2013)^{b}\end{array}$ & $\begin{array}{r}\text { Brilli et } \\
\text { al. (2016) }\end{array}$ & $\begin{array}{r}\text { This study (21 } \\
\text { days June })^{\mathrm{c}}\end{array}$ & $\begin{array}{r}\text { Kaser et } \\
\text { al. }(2013 a)^{c}\end{array}$ \\
\hline 33.0335 & $\mathrm{CH}_{5} \mathrm{O}^{+}$ & $\begin{array}{r}0.965^{\mathrm{a}} \\
(-0.044 / 1.010)\end{array}$ & $\begin{array}{r}1.168 \\
(-0.365 / 1.533)\end{array}$ & $\begin{array}{r}1.655 \\
(-0.102 / 1.757)\end{array}$ & 0.884 & $2.09^{c}$ & $3.53^{\mathrm{c}}$ \\
\hline 41.0386 & $\mathrm{C}_{3} \mathrm{H}_{5}^{+}$ & $\begin{array}{r}0.050^{\mathrm{a}} \\
(-0.001 / 0.051)\end{array}$ & & $\begin{array}{r}0.085 \\
(-0.005 / 0.089)\end{array}$ & & $0.10^{\mathrm{c}}$ & \\
\hline 42.0338 & $\mathrm{C}_{2} \mathrm{H}_{4} \mathrm{~N}^{+}$ & $\begin{array}{r}0.003 \\
(-0.008 / 0.011)\end{array}$ & $\begin{array}{r}0.046 \\
(-0.005 / 0.051)\end{array}$ & & & $<0.01^{\mathrm{c}}$ & \\
\hline 43.0178 & $\mathrm{C}_{2} \mathrm{H}_{3} \mathrm{O}^{+}$ & $\begin{array}{r}0.027^{\mathrm{a}} \\
(-0.011 / 0.038)\end{array}$ & & $\begin{array}{r}0.075 \\
(-0.001 / 0.076)\end{array}$ & & $0.07^{\mathrm{c}}$ & \\
\hline 45.0335 & $\mathrm{C}_{2} \mathrm{H}_{5} \mathrm{O}^{+}$ & $\begin{array}{r}0.099^{\mathrm{a}} \\
(-0.004 / 0.103)\end{array}$ & $\begin{array}{r}0.228 \\
(-0.001 / 0.229)\end{array}$ & $\begin{array}{r}0.133 \\
(-0.016 / 0.148)\end{array}$ & 0.004 & $0.17^{\mathrm{c}}$ & $1.05^{\mathrm{c}}$ \\
\hline 57.0699 & $\mathrm{C}_{4} \mathrm{H}_{9}^{+}$ & $\begin{array}{r}0.199 \\
(0 / 0.199)\end{array}$ & & $\begin{array}{r}0.016 \\
(-0.011 / 0.027)\end{array}$ & & $0.30^{c}$ & \\
\hline 59.0491 & $\mathrm{C}_{3} \mathrm{H}_{7} \mathrm{O}^{+}$ & $\begin{array}{r}0.297^{\mathrm{a}} \\
(-0.001 / 0.297)\end{array}$ & $\begin{array}{r}0.335 \\
(-0.01 / 0.345)\end{array}$ & $\begin{array}{r}0.281 \\
(-0.004 / 0.286)\end{array}$ & 0.035 & $0.48^{\mathrm{c}}$ & $0.13^{\mathrm{c}}$ \\
\hline 60.0471 & unknown & $\begin{array}{r}0.022^{\mathrm{a}} \\
(-0.005 / 0.026)\end{array}$ & & & & $0.03^{\mathrm{c}}$ & \\
\hline 61.0284 & $\mathrm{C}_{2} \mathrm{H}_{5} \mathrm{O}_{2}^{+}$ & $\begin{array}{r}0.044^{\mathrm{a}} \\
(-0.003 / 0.048)\end{array}$ & $\begin{array}{r}0.214 \\
(-0.096 / 0.311)\end{array}$ & $\begin{array}{r}0.413 \\
(-0.005 / 0.418)\end{array}$ & & $0.09^{\mathrm{c}}$ & $1.64^{\mathrm{c}}$ \\
\hline 67.0542 & $\mathrm{C}_{5} \mathrm{H}_{7}^{+}$ & $\begin{array}{r}0.006^{\mathrm{a}} \\
(-0.001 / 0.007)\end{array}$ & & $\begin{array}{r}0.012 \\
(-0.004 / 0.017)\end{array}$ & & $0.01^{\mathrm{c}}$ & \\
\hline 69.0352 & unknown & $\begin{array}{r}0.013^{\mathrm{a}} \\
(-0.001 / 0.013)\end{array}$ & & & & $0.03^{\mathrm{c}}$ & \\
\hline 69.0699 & $\mathrm{C}_{5} \mathrm{H}_{9}^{+}$ & $\begin{array}{r}0.083^{\mathrm{a}} \\
(-0.003 / 0.086)\end{array}$ & $\begin{array}{r}6.466 \\
(0 / 6.466)\end{array}$ & $\begin{array}{r}0.025 \\
(-0.001 / 0.025)\end{array}$ & 1.009 & $0.17^{\mathrm{c}}$ & $5.87^{\mathrm{c}}$ \\
\hline 70.0696 & unknown & $\begin{array}{r}0.007^{\mathrm{a}} \\
(-0.001 / 0.008)\end{array}$ & & & & $0.01^{\mathrm{c}}$ & \\
\hline 89.0386 & $\mathrm{C}_{7} \mathrm{H}_{5}^{+}$ & $\begin{array}{r}0.001 \\
(-0.004 / 0.005)\end{array}$ & & & & $>-0.01^{\mathrm{c}}$ & \\
\hline 93.0699 & $\mathrm{C}_{7} \mathrm{H}_{9}^{+}$ & $\begin{array}{r}0.020^{\mathrm{a}} \\
(-0.001 / 0.021)\end{array}$ & & $\begin{array}{r}0.058 \\
(0 / 0.058)\end{array}$ & & $0.04^{\mathrm{c}}$ & \\
\hline 99.0769 & unknown & $\begin{array}{r}0.001 \\
(-0.004 / 0.004)\end{array}$ & & & & $0.01^{\mathrm{c}}$ & \\
\hline 137.1325 & $\mathrm{C}_{10} \mathrm{H}_{17}^{+}$ & $\begin{array}{r}0.430 \\
(0 / 0.430)\end{array}$ & $\begin{array}{r}0.219 \\
(-0.001 / 0.219)\end{array}$ & $\begin{array}{r}0.290 \\
(0 / 0.290)^{2}\end{array}$ & 0.005 & $0.63^{c}$ & $0.71^{\mathrm{c}}$ \\
\hline Net flux is & study & 2.07 & 9.78 & 4.43 & 1.99 & $3.93^{c}$ & $15.07^{\mathrm{c}}$ \\
\hline Length of & ata set (days) & 21 & 21 & 33 & 129 & 21 & 31 \\
\hline Highest el & itted compound & methanol & isoprene & methanol & isoprene & methanol & $\begin{array}{r}\text { MBO and } \\
\text { isoprene }\end{array}$ \\
\hline No. of cor & pounds with flux & 17 & 29 & 494 & 13 & 17 & $15^{\mathrm{d}}$ \\
\hline
\end{tabular}

a Values for downward flux are under the respective limit of detection $\left(2 \sigma_{\text {ind }}\right) . \sigma_{\text {ind }}$ was calculated using the propagation of error formula and the standard deviation at the borders of the individual 30 min CCFs. ${ }^{b}$ Park et al. (2013) published the $24 \mathrm{~h}$ values of the identified masses, therefore no comparison of the unidentified compounds was possible. ${ }^{\mathrm{c}} 8 \mathrm{~h}$ average daytime values (10:00-16:00). ${ }^{\mathrm{d}} 8$ of the 15 compounds were only recorded after a hail storm event.

by the lower average temperature of $15^{\circ} \mathrm{C}$ and the lower PAR of $406 \mu \mathrm{mol} \mathrm{m} \mathrm{m}^{-2} \mathrm{~s}^{-1}$ during the longer period.

\subsection{EC VOC fluxes above different ecosystems}

Ecosystems and their phenomenology define which VOCs are released. In this study 25 compounds were exchanged, with 17 of them emitted during the 21 days in June. The mea- 


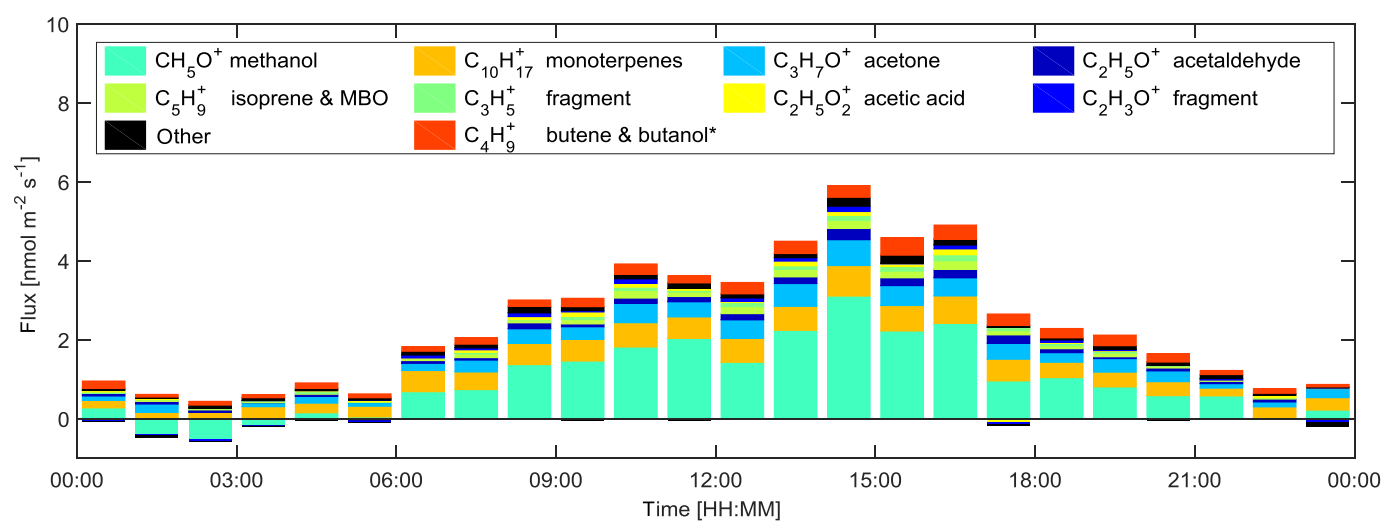

Figure 6. Diurnal variation of the nine most emitted compounds during the 21 days of measurement in June. The remaining compounds are summed up as "other". The high variation in the flux seen in Fig. 4 (diurnal plot of 9 days of measurements in June) is reduced, as meteorological events (e.g., rain) have less impact on the result. * The butene + butanol exchange is anthropogenic and thereby not emitted by the forest (Sect. 3.4).

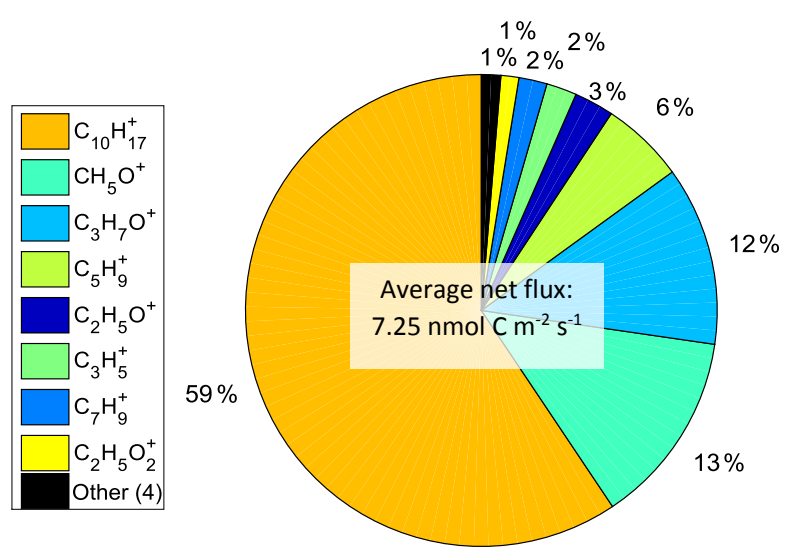

Figure 7. Average net flux of the major carbon emitters (June). Compounds whose elemental composition could not be identified were disregarded. See Table 1 for the corresponding compound names. The butene + butanol emissions were disregarded in this figure.

sured emissions and the observed amount depend on many environmental aspects as well as meteorology, experimental setup (e.g., inlet length) and length and time of the measurements. The $24 \mathrm{~h}$ net emission during 21 days in June were $2.07 \mathrm{nmol} \mathrm{m}^{-2} \mathrm{~s}^{-1}$, which is on the low side compared to other PTR-TOF fluxes from other ecosystems (Table 2). In the Pinus sylvestris (Scots pine) forest in Hyytiälä, the major emissions in June were from methanol, monoterpenes and acetone. Measurement gaps were excluded when calculating the length of the data sets. Most of the studies used a data set between 20 and 35 days, Brilli et al. (2016) being an exception with 129 days. All measurements were carried out around summer, when the plant activities were high. This study used data from June, Park et al. (2013) and Schallhart et al. (2016) used data from June and July, Kaser et al. (2013a)
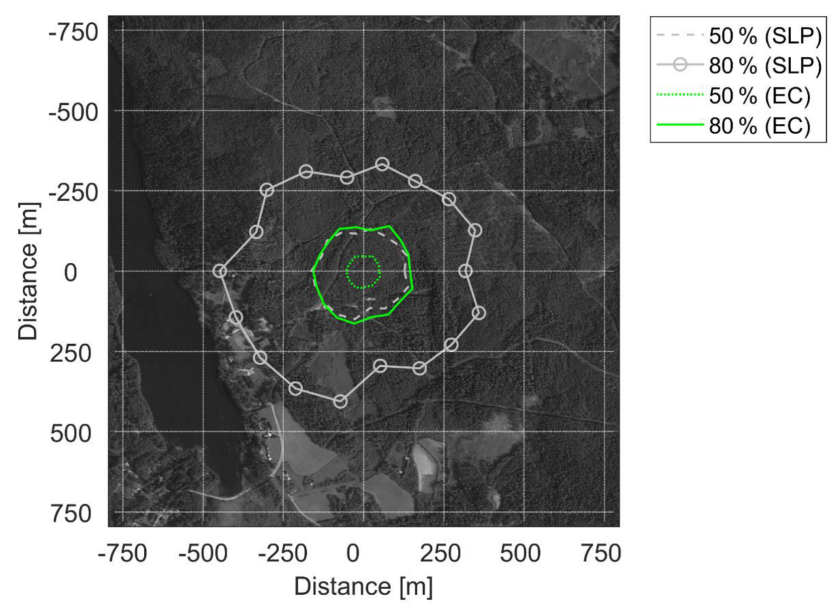

Figure 8. Footprint of the SLP and EC method. The higher nominal measurement height of the SLP fluxes increases the footprint drastically, when compared to the EC measurements. This could be a possible cause for the discrepancies in the results.

used data from August and September and Brilli et al. (2016) used data from June until the end of October. Out of these studies, the lowest $24 \mathrm{~h}$ net flux was measured at a 2-yearold Populus (poplar) plantation (Brilli et al., 2015) in Belgium, with $1.99 \mathrm{nmol} \mathrm{m}^{-2} \mathrm{~s}^{-1}$. Isoprene was emitted most, followed by methanol, acetone and the group of green leaf volatiles (measured via a fragment). The low emission can be partly explained by the long measurement period that extended over the summer. Park et al. (2013) reported a net flux of $4.43 \mathrm{nmol} \mathrm{m}^{-2} \mathrm{~s}^{-1}$ above an orange grove. The most emitted compounds were methanol, acetic acid, monoterpenes and acetone. The study was exceptional because it measured significant fluxes for several hundreds of VOCs. Despite that, the highest net flux was measured by Schallhart et al. (2016) above a mixed Quercus (oak) Carpinus betulus 
(hornbeam) forest with $9.78 \mathrm{nmol} \mathrm{m}^{-2} \mathrm{~s}^{-1}$. In their study the most emitted compounds were isoprene, methanol, acetone and methyl vinyl ketone + methacrolein. The high emissions can be explained by the ecosystem, as oaks are known to be strong isoprene emitters (e.g., Potosnak et al., 2014). Kaser et al. (2013a) reported $8 \mathrm{~h}$ daytime fluxes only, so a direct comparison with the $24 \mathrm{~h}$ net flux from the other studies is not possible. However, the Pinus ponderosa (Ponderosa pine) flux was dominated by $\mathrm{MBO}+$ isoprene fluxes, followed by methanol and acetic acid. The net flux is almost a factor of 4 higher than in boreal forest in Hyytiälä. However, it should be noted that the day length in summer is much longer in Hyytiälä $\left(62^{\circ} \mathrm{N}\right)$ when compared to the Ponderosa pine forest in Colorado $\left(39^{\circ} \mathrm{N}\right)$ and, therefore, elevated emissions last longer than $8 \mathrm{~h}$.

The net carbon flux of the VOCs during the campaign in Hyytiälä was $7.25 \mathrm{nmol} \mathrm{C} \mathrm{m}^{-2} \mathrm{~s}^{-1}$ (Fig. 7). The group of monoterpenes was the highest emitter of carbon with $59 \%$ of the net carbon exchange, followed by methanol (13\%), acetone $(12 \%)$, isoprene $+\mathrm{MBO}(5 \%)$ and acetaldehyde $(3 \%)$. The $\mathrm{C}_{3} \mathrm{H}_{5}^{+}$fragment, toluene $+p$-cymene contributed $2 \%$, while acetic acid and the sum of the remaining compounds both contributed $1 \%$. Compared to the $\mathrm{CO}_{2}$ net ecosystem exchange (NEE) of $-4266 \mathrm{nmol} \mathrm{C} \mathrm{m}^{-2} \mathrm{~s}^{-1}$, the carbon released as VOC represents less than $0.2 \%$ of the NEE of the corresponding period. In Brilli et al. (2016) the VOCs, with $6.36 \mathrm{nmol} \mathrm{C} \mathrm{m}^{-2} \mathrm{~s}^{-1}$, represent $0.8 \%$ of the carbon exchange and in Schallhart et al. (2016) VOCs had a carbon flux of $41.8 \mathrm{nmol} \mathrm{C} \mathrm{m}^{-2} \mathrm{~s}^{-1}$, which corresponded to $1.7 \%$ of the NEE. Juráñ et al. (2017) measured EC exchange of VOCs in a Picea abies (Norway spruce) forest in the Czech Republic. In their study the ratio between the carbon released from VOCs and the NEE was $0.3 \%$ during the 5 days of data in July. Other ratios from DEC studies using PTR-Quad are $0.7 \%$ above an oil palm plantation (E. guineensis $\times E$. oleifera hybrid) in Malaysia (Misztal et al., 2011) and 0.16 and $0.24 \%$ above two P. halepensis (Aleppo pine) forests in Israel (Seco et al., 2017).

There was an order of magnitude difference between the proportion of net assimilated carbon released as VOCs between a Mediterranean oak-hornbeam forest (Schallhart et al., 2016) and a boreal evergreen forest. Also, a middle European poplar plantation (Brilli et al., 2016) clearly released a higher proportion of the assimilated carbon as VOCs than a boreal site in this study. The spruce forest in central Europe came closest to the results in Hyytiälä. These findings strongly imply that there are significant differences between the ecosystems in how they allocate carbon to VOCs; however, the reasons for that are rather related to light and thermal conditions, species selection and age structure and soil properties than to the efficiency of an ecosystem to produce VOCs as an indefinable concept. In boreal ecosystems with relatively northern locations, the majority of carbon assimilation is concentrated within a couple of months around midsummer with very short nights. The structure of forest and the tree species are effective in utilizing the high light availability during the summer months, whereas in more southern locations the light availability and thermal conditions allow more even carbon assimilation throughout a considerably longer period. This partly explains the lower proportion of $\mathrm{C}$ released as VOCs determined in this study, when compared to those measured in more southern locations. Additionally, the constitutive emission capacities of boreal evergreen species are known to be low when compared to deciduous species more common in central and southern Europe (Rinne et al., 2009; Ghirardo et al., 2010).

\subsection{Comparison between PTR-TOF and PTR-Quad measurements}

Generally, the EC method detected more masses than the SLP measurements, which can be explained by the preselection of the masses to be measured by the PTR-Quad and its low duty cycle. The comparison between PTR-TOF using the EC method and the PTR-Quad using the SLP method (see Rantala et al., 2015) between April and June revealed 12 more compounds with exchange using the EC method (see Tables 1, 2 and 3). The PTR-TOF measures all VOCs in a certain mass range, while the PTR-Quad needs a preselection of masses, limiting the number of recorded compounds. However, the classification if a compound has a measurable flux is different between the two methods (Sect. 2.3 and Rantala et al., 2015). Even though the EC method found almost twice the number of compounds with exchange, the total exchange was on the same order of magnitude for both methods. The discrepancy between the results of the two measurements is mainly due to instrument and method differences. The horizontal distance between the inlets of these two instruments was just $25 \mathrm{~m}$ and the PTR-Quad was measuring from $13 \mathrm{~m}$ higher (calculated height $36 \mathrm{~m}$ ) than the PTR-TOF, leading to a larger footprint area for the SLP method. This can be seen in Fig. 8, where the daytime (07:00 to 19:00) footprint calculated according to Kormann and Meixner (2002) for the SLP and EC method are presented. Even though the nominal measurement height of the SLP was $36 \mathrm{~m}$, the shown footprint is calculated for $33 \mathrm{~m}$, as this was the closest height with horizontal wind measurements.

The main compounds (methanol, acetone and monoterpenes) were detected by both methods. $\mathrm{C}_{4} \mathrm{H}_{9}^{+}(57.0699 \mathrm{Da})$ could not be measured by the PTR-Quad, as the unit mass resolution of the instrument is unable to separate the signal from the water cluster isotope $\mathrm{H}_{7} \mathrm{O}_{2}^{18} \mathrm{O}^{+}$(57.0432 Da). In contrast, the SLP measurements observed a flux of ethanol + formic acid which was not detected by the PTRTOF. Interestingly, formic acid fluxes have also been observed at SMEAR II using the EC method with an iodideadduct high-resolution time-of-flight chemical ionization mass spectrometer in 2014 (Schobesberger et al., 2016). Other VOC fluxes, which were not detected by the PTR-TOF were methyl ethyl ketone $(73 \mathrm{Da})$, a fragment of the green 

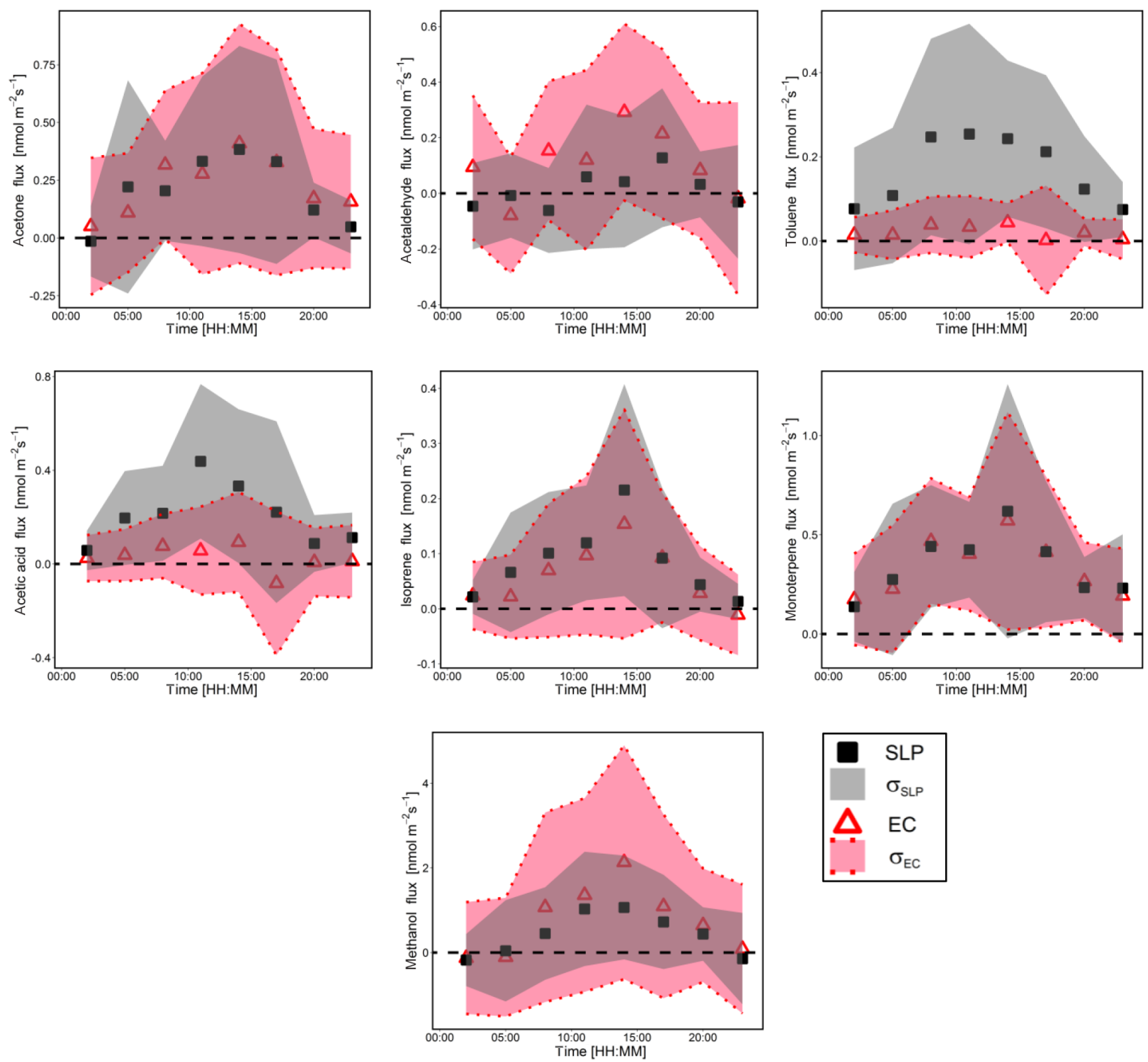

Figure 9. Diurnal mean and standard deviation of the eddy covariance (red triangles) and the surface layer profile (black squares) flux of the major compounds measured by EC and SLP. The data are from April to the end of June 2013.

leaf volatiles $(83 \mathrm{Da})$ and MBO $(87 \mathrm{Da})$. The formaldehyde fluxes were not included in the comparison, as the PTR-TOF, detected them just during the first 8 days in June, during which the PTR-Quad had technical problems resulting in less than 10 overlapping data points from the two instruments.

Overall, the flux values used for the comparison were small, as the compared data included values from April and May, and unfortunately the SLP measurements were not working during the warm, i.e., high flux, period in the beginning of June. Thus, the comparison was done using flux values that were mostly close to the detection limits of the
EC and the SLP setups. The uncertainties of the turbulence measurements and noise of the VOC measurements, together with the different measurement setups, methods and footprints was seen in the scatter of the compared data, which affected correlation, fitting parameters and their uncertainties (Table 3).

However, the magnitude of the studied fluxes as well as their diurnal patterns were comparable for methanol, acetone, isoprene and monoterpenes (Table 3 and Fig. 9). The monoterpene and methanol fluxes measured by the two methods showed the highest correlation, which was barely above 
Table 3. Statistics of the major compounds of SLP and the EC flux measurements. The EC fluxes are in bold, whereas the SLP fluxes are written in normal text. The fitting parameters describe the slope (upper value) and the intercept (lower value) of the linear model between the EC and the SLP fluxes. $N$ is the number of the data points for each compound. The numbers in parenthesis are lower and upper quartiles. The unit for the mean, median, intercept and quantile values is $n m o l \mathrm{~m}^{-2} \mathrm{~s}^{-1}$.

\begin{tabular}{|c|c|c|c|c|c|c|}
\hline Nominal mass & $R^{2}$ & Mean & Median & 5 and $95 \%$ quant. & Fitting & $N$ \\
\hline \multirow[t]{2}{*}{33 (methanol) $^{\mathrm{a}}$} & 0.374 & 0.447 & $0.204(-0.177,1.161)$ & $-1.602,2.920$ & $0.810 \pm 0.220$ & 92 \\
\hline & & 0.553 & $0.730(-0.931,1.910)$ & $-2.107,3.296$ & $0.171 \pm 0.306$ & \\
\hline \multirow[t]{2}{*}{42 (acetonitrile) } & 0.003 & -0.009 & $-0.003(-0.026,0.005)$ & $-0.052,0.026$ & $0.296 \pm 1.545$ & 55 \\
\hline & & -0.017 & $-0.050(-0.103,0.072)$ & $-0.209,0.228$ & $-0.015 \pm 0.040$ & \\
\hline \multirow[t]{2}{*}{45 (acetaldehyde) } & 0.033 & 0.019 & $0.024(-0.106,0.131)$ & $-0.382,0.481$ & $-0.195 \pm 0.310$ & 49 \\
\hline & & 0.063 & $0.114(-0.116,0.245)$ & $-0.406,0.507$ & $0.067 \pm 0.082$ & \\
\hline \multirow[t]{2}{*}{59 (acetone) } & 0.051 & 0.176 & $0.090(0.004,0.262)$ & $-0.156,0.696$ & $0.242 \pm 0.191$ & 119 \\
\hline & & 0.173 & $0.210(-0.046,0.373)$ & $-0.469,0.677$ & $0.131 \pm 0.074$ & \\
\hline \multirow[t]{2}{*}{$61(\text { acetic acid })^{\mathrm{a}, \mathrm{b}}$} & 0.064 & 0.336 & $0.244(0.059,0.504)$ & $0.003,1.052$ & $0.116 \pm 0.130$ & 49 \\
\hline & & 0.025 & $0.058(-0.029,0.093)$ & $-0.115,0.195$ & $-0.014 \pm 0.061$ & \\
\hline \multirow[t]{2}{*}{69 (isoprene + MBO) } & 0.127 & 0.082 & $0.033(0.005,0.091)$ & $-0.009,0.383$ & $0.274 \pm 0.160$ & 82 \\
\hline & & 0.035 & $0.035(-0.013,0.052)$ & $-0.054,0.104$ & $0.013 \pm 0.025$ & \\
\hline \multirow[t]{2}{*}{93 (toluene $+p$-cymene) } & 0.089 & 0.138 & $0.081(0.024,0.209)$ & $-0.063,0.519$ & $0.088 \pm 0.061$ & 88 \\
\hline & & 0.027 & $0.037(-0.013,0.052)$ & $-0.054,0.104$ & $0.015 \pm 0.014$ & \\
\hline \multirow[t]{2}{*}{137 (monoterpenes) } & 0.364 & 0.282 & $0.208(0.084,0.365)$ & $0.023,0.754$ & $0.503 \pm 0.123$ & 116 \\
\hline & & 0.261 & $0.225(0.135,0.349)$ & $0.019,0.583$ & $0.118 \pm 0.051$ & \\
\hline
\end{tabular}

${ }^{\text {a }}$ Sensitivity was derived from the instrumental transmission curve for the PTR-Quad. ${ }^{b}$ The acetic acid sensitivity was estimated.
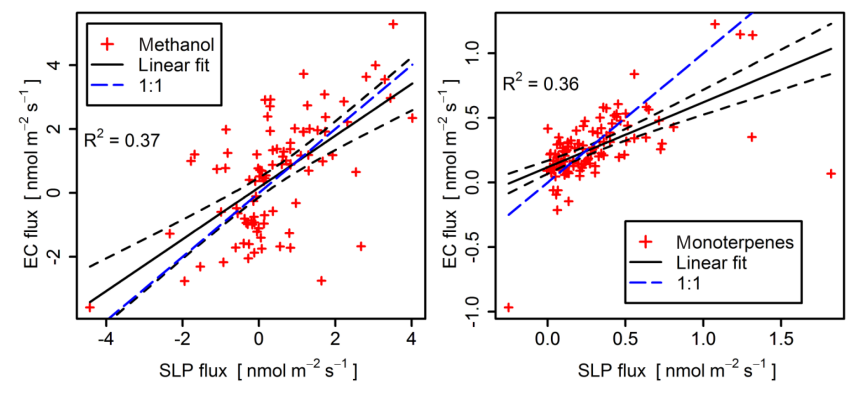

Figure 10. The eddy covariance fluxes against the surface layer gradient fluxes (methanol and monoterpenes, April-June 2013). In addition to the actual scatter plots, the figures include linear fits (black solid lines) with confidence intervals (black dashed lines) and $R^{2}$ parameters.

0.6 (Fig. 10). The fitted slopes of the scatter plots for acetone, isoprene and the monoterpenes were far from unity, as best $R^{2}$ values were calculated when using high intercepts.

The fluxes of acetonitrile, acetaldehyde, acetic acid and toluene $+p$-cymene did not agree similarly well. Therefore, the correlations between the methods were poor for rest of the compounds. The toluene $+p$-cymene flux discrepancy was likely caused by a different detection of the toluene $+p$ cymene signal in the two instrument and not due to the different flux methods. The toluene $+p$-cymene measurements at mass 93 with PTR-Quad and 93.0454 with PTR-TOF resulted in different concentration values and should be handled with care. Different fragmentation from $p$-cymene, in- fluence from two other mass peaks seen at nominal mass 93 (92.5 to $93.5 \mathrm{Da}$ ) and/or unsuccessful calibrations may probably explain the observed differences. Kajos et al. (2015) reported similar discrepancies in toluene $+p$-cymene concentration measurements with the PTR-Quad at the site. Also, acetic acid fragments when measured with the PTR method (Baasandorj et al., 2015). Higher fragmentation in the PTRTOF (61.0284 Da), when compared to the PTR-Quad (60.5 to $61.5 \mathrm{Da}$ ), could account for a part of the lower acetic acid fluxes with the EC method. However, even when the acetic acid main fragment $\mathrm{C}_{2} \mathrm{H}_{3} \mathrm{O}^{+}$(Baasandorj et al., 2015) is taken into account, in addition to the signal from the parent mass, the EC fluxes are still lower than the SLP results. Another uncertainty comes from the lack of acetic acid in the calibration standard. For the uncalibrated compounds the sensitivity can be calculated (Sect. 2.2; Rantala et al., 2015), but they are more uncertain and can lead to systematic discrepancies. A recent study compared PTR-TOF measurements with gas chromatography mass spectrometer measurements, as in this study as well, the PTR-TOF underestimated the acetic acid concentration (Helén et al., 2017). The authors suggested that a possible memory effect in the inlet or instrument could lead to this underestimation, which was also reported by de Gouw et al. (2003). This effect could lead to an additional attenuation of the acetic acid signal and thus decrease the measured flux.

In addition to the differences between the PTR-Quad used in SLP and the PTR-TOF used in EC, the flux calculation methods could also lead to discrepancies, such as the SLP fluxes having larger footprints, which were seen as different 

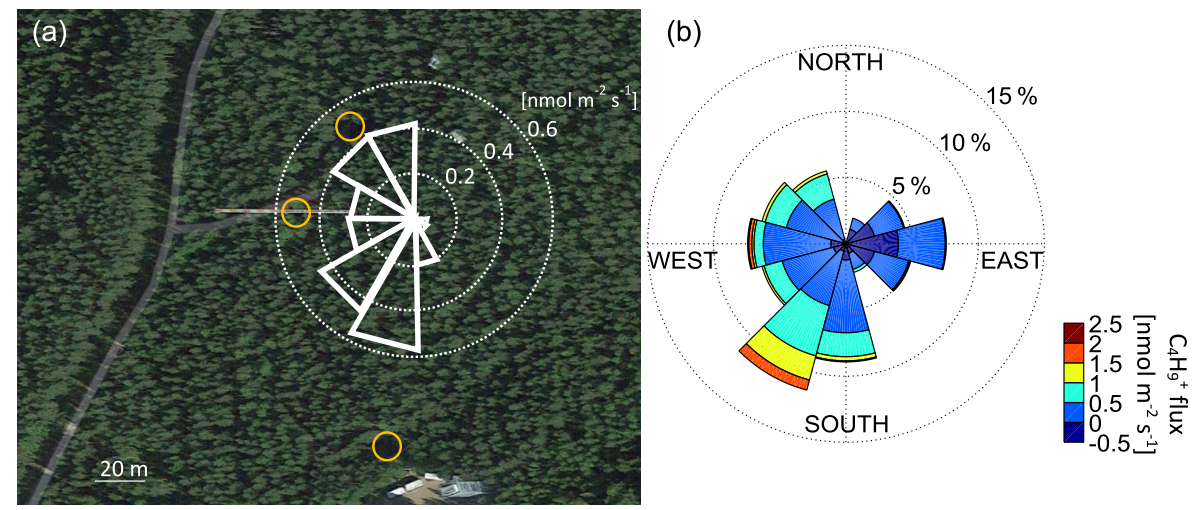

Figure 11. On the left side the average $\mathrm{C}_{4} \mathrm{H}_{9}^{+}$flux is shown (data of the whole campaign) in white. The orange circles illustrate the locations of the aerosol instruments, which use butanol. The average fluxes from north to south-southeast are under $0.05 \mathrm{nmol} \mathrm{m}^{-2} \mathrm{~s}^{-1}$. The map was taken from Google Maps (Image @ 2016 Google; map data @ 2016 Google). The wind rose of the $\mathrm{C}_{4} \mathrm{H}_{9}^{+}$fluxes is shown on the right.

flux values, or the SLP or the EC method working improperly for these compounds. One should also note that the comparison was based on a small data set only (Table 3) and, thus, random variations also affect the results. The net flux for all compounds in Table 3 was $1.120 \mathrm{nmol} \mathrm{m}^{-2} \mathrm{~s}^{-1}$ for the PTRTOF and $1.471 \mathrm{nmol} \mathrm{m}^{-2} \mathrm{~s}^{-1}$ for the PTR-Quad. If the net flux is calculated for all the compounds, which were measured by the individual instrument, it is $1.252 \mathrm{nmol} \mathrm{m}^{-2} \mathrm{~s}^{-1}$ for the PTR-TOF, not including butene + butanol, and $1.802 \mathrm{nmol} \mathrm{m}^{-2} \mathrm{~s}^{-1}$ for the PTR-Quad.

\subsection{Anthropogenic flux of $\mathrm{C}_{4} \mathrm{H}_{9}^{+}$}

The identification of the compound with the elemental composition of $\mathrm{C}_{4} \mathrm{H}_{9}^{+}$is problematic as it could be protonated butene, which can be emitted by forests (Goldstein et al., 1996; Hakola et al., 1998) and from anthropogenic sources (Harley et al., 1992; Na et al., 2004). Another possible contribution to the $\mathrm{C}_{4} \mathrm{H}_{9}^{+}$signal comes from the fragmentation of butanol, which as many other alcohols, can lose an OH during ionization (Spanel and Smith, 1997). Denzer et al. (2014) reported that the most abundant signal of butanol, when measured with PTR-Quad, is for the $\mathrm{C}_{4} \mathrm{H}_{9}^{+}$mass. Fragmentation tests using the PTR-TOF confirmed this. In Fig. 11 the average $\mathrm{C}_{4} \mathrm{H}_{9}^{+}$flux from different wind sectors and the wind rose for the individual 30 min $\mathrm{C}_{4} \mathrm{H}_{9}^{+}$fluxes are shown. The sources of the $\mathrm{C}_{4} \mathrm{H}_{9}^{+}$ clearly lay in the western part of the forest as there are just low emissions and depositions in the east side. The highest average flux of $\mathrm{C}_{4} \mathrm{H}_{9}^{+}$came from south-southwest $\left(195^{\circ}\right)$ with $0.57 \mathrm{nmol} \mathrm{m}^{-2} \mathrm{~s}^{-1}$ while another maximum lay in north-northwest $\left(345^{\circ}\right)$ with $0.42 \mathrm{nmol} \mathrm{m}^{-2} \mathrm{~s}^{-1}$. The cottages where the butanol using aerosol measurements, condensation particle counters (CPCs), of the station are located (Fig. 11, orange circles), lie approximately in these directions. An additional CPC was mounted on a mast located west of the VOC flux measurements. Therefore we conclude that the $\mathrm{C}_{4} \mathrm{H}_{9}^{+}$signal is mainly from butanol used by the aerosol instruments and thus the flux is anthropogenic. During 2013, approximately $100 \mathrm{~L}$ of butanol were evaporated in the CPCs at the station. During our measurements the contribution of the butanol fragment to the total emission was $63 \%$ during the measurement period in April and $11 \%$ in the May period and $8 \%$ during the measurements in June.

\section{Conclusions}

Overall, the exchange of 25 compounds was observed over a boreal Scots pine forest. During the transition from early spring to mid-summer the net flux increased by a factor of 5 and the number of compounds changed from 3 to 19 . The highest emissions occurred in late afternoon, while deposition was observed mainly at night. The majority of the net VOC flux was comprised of methanol, monoterpenes, acetone and butene + butanol. The measured butene + butanol flux was most likely a fragment of butanol and created by evaporation in the particle counters used at SMEAR II. Twelve compounds were measured either only in May or June, which implies a strong seasonal cycle and a high diversity of VOC emissions from the boreal forest in Hyytiälä.

Compared to EC fluxes from other ecosystems measured with the PTR-TOF, the VOC emission in the boreal forest was small, $2.16 \mathrm{nmol} \mathrm{m}^{-2} \mathrm{~s}^{-1}$, even though the measurements in June had the longest day length, up to $19.5 \mathrm{~h}$. In relation to the $\mathrm{CO}_{2}$ exchange, the VOCs are only less than $0.2 \%$ compared to the net ecosystem carbon exchange.

The EC fluxes measured with PTR-TOF and the SLP fluxes measured with PTR-Quad had similar results for the main flux compounds - methanol, monoterpenes and acetone - thus confirming the feasibility of the indirect SLP method at the site. For small fluxes, like acetonitrile, isoprene and acetaldehyde the results were affected by noise. Toluene $+p$ cymene and acetic acid show significant differences, which 
could hint at differences in the fragmentation patterns of the instruments. Further research is still needed to close the gap between the fluxes measured by the two instruments.

Therefore, long-time measurements with the PTR-Quad or other instruments, which create less data and do not need such work intensive data post-processing as the PTRTOF, are essential. If a research network of sites with VOC flux measurements is established in the future, cheaper and easier-to-use instruments are needed (Rinne et al., 2016). Still, intensive campaigns with more selective instruments are important assets to understand biosphere-atmosphere exchanges and air chemistry in different ecosystems.

Data availability. The data are available upon request from the corresponding author.

Competing interests. The authors declare that they have no conflict of interest.

Special issue statement. This article is part of the special issue "Pan-Eurasian Experiment (PEEX)". It is not associated with a conference.

Acknowledgements. We would like to thank Heikki Junninen and the tofTools team for providing tools for mass spectrometry analysis. We are further grateful to the Hyytiälä staff, especially to Janne Levula, Heikki Laakso, Matti Loponen and Reijo Pilkottu for all the help at SMEAR II, as well as Pasi Aalto, Erkki Siivola and Frans Korhonen for their technical help in Helsinki. Also thanks to Pasi Kolari and Petri Keronen for providing the meteorological data. This research received funding from the Academy of Finland Centre of Excellence program (project number 272041).

Edited by: Martin Heimann

Reviewed by: three anonymous referees

\section{References}

Aalto, J., Kolari, P., Hari, P., Kerminen, V.-M., Schiestl-Aalto, P., Aaltonen, H., Levula, J., Siivola, E., Kulmala, M., and Bäck, J.: New foliage growth is a significant, unaccounted source for volatiles in boreal evergreen forests, Biogeosciences, 11, 13311344, https://doi.org/10.5194/bg-11-1331-2014, 2014.

Aalto, J., Porcar-Castell, A., Atherton, J., Kolari, P., Pohja, T., Hari, P., Nikinmaa, E., Petäjä, T., and Bäck, J.: Onset of photosynthesis in spring speeds up monoterpene synthesis and leads to emission bursts, Plant Cell Environ., 38, 11, 2299-2312, 2015.

Aaltonen, H., Pumpanen, J., Pihlatie, M., Hakola, H., Hellén, H., Kulmala, L., Vesala, T., and Bäck, J.: Boreal pine forest floor biogenic volatile organic compound emissions peak in early summer and autumn, Agr. Forest Meteorol., 151, 682-691, 2011.
Aaltonen, H., Aalto, J., Kolari, P., Pihlatie, M., Pumpanen, J., Kulmala, M., Nikinmaa, E., Vesala, T., and Bäck, J.: Continuous VOC flux measurements on boreal forest floor, Plant Soil, 369, 241-256, 2013.

Aubinet, M., Vesala, T., and Papale, D.: Eddy Covariance: A Practical Guide to Measurement and Data Analysis, Springer Atmospheric Sciences, Netherlands, 2012.

Baasandorj, M., Millet, D. B., Hu, L., Mitroo, D., and Williams, B. J.: Measuring acetic and formic acid by proton-transferreaction mass spectrometry: sensitivity, humidity dependence, and quantifying interferences, Atmos. Meas. Tech., 8, 13031321, https://doi.org/10.5194/amt-8-1303-2015, 2015.

Bäck, J., Aaltonen, H., Hellén, H., Kajos, M. K., Patokoski, J., Taipale, R., Pumpanen, J., and Heinonsalo, J.: Variable emissions of microbial volatile organic compounds (MVOCs) from root-associated fungi isolated from Scots pine, Atmos. Environ., 44, 3651-3659, 2010

Bäck, J., Aalto, J., Henriksson, M., Hakola, H., He, Q., and Boy, M.: Chemodiversity of a Scots pine stand and implications for terpene air concentrations, Biogeosciences, 9, 689-702, https://doi.org/10.5194/bg-9-689-2012, 2012.

Baldocchi, D.: Measuring fluxes of trace gases and energy between ecosystems and the atmosphere - the state and future of the eddy covariance method, Glob. Change Biol., 20, 3600-3609, https://doi.org/10.1111/gcb.12649, 2014.

Brilli, F., Gioli, B., Fares, S., Terenzio, Z., Zona, D., Gielen, B., Loreto, F., Janssens, Ivan, A., and Ceulemans, R.: Rapid leaf development drives the seasonal pattern of volatile organic compound (VOC) fluxes in a "coppiced'; bioenergy poplar plantation, Plant Cell Environ., 39, 539-555, https://doi.org/10.1111/pce.12638, 2016.

de Gouw, J. A. and Warneke, C.: Measurements of volatile organic compounds in the earth's atmosphere using protontransferreaction mass spectrometry, Mass Spectrom. Rev., 26, 223-257, https://doi.org/10.1002/mas.20119, 2006.

de Gouw, J. A., Goldan, P. D., Warneke, C., Kuster, W. C., Roberts, J. M., Marchewka, M., Bertman, S. B., Pszenny, A. A. P., and Keene, W. C.: Validation of proton transfer reaction-mass spectrometry (PTR-MS) measurements of gas-phase organic compounds in the atmosphere during the New England Air Quality Study (NEAQS) in 2002, J. Geophys. Res., 108, ACH 10-1-ACH 10-18, https://doi.org/10.1029/2003JD003863, 2003.

Denzer, M. Y., Gailer, S., Kern, D. W., Sclumm, L. P., Thuerauf, N., Kornhuber, J., Buettner A., and Beauchamp J.: Quantitative Validation of the n-Butanol Sniffin' Sticks Threshold Pens, Chem. Percept., 7, 91-101, https://doi.org/10.1007/s12078-014-9168-1, 2014.

Foken, T. and Wichura, B.: Tools for quality assessment of surfacebased flux measurements, Agr. Forest Meteorol., 78, 83-105, 1996.

Galbally, I. E. and Kirstine, W.: The production of methanol by flowering plants and the global cycle of methanol, J. Atmos. Chem., 43, 195-229, 2002.

Ghirardo, A., Koch, K., Taipale, R., Zimmer, I., Schnitzler, J.-P., and Rinne, J.: Determination of de novo and pool emissions of terpenes from four common boreal/alpine trees by ${ }^{13} \mathrm{CO}_{2}$ labelling and PTR-MS analysis, Plant Cell Environ., 33, 781-792, https://doi.org/10.1111/j.1365-3040.2009.02104.x, 2010. 
Goldstein, A. H., Fan, S. M., Goulden, M. L., Munger, J. W., and Wofsy, S. C.: Emissions of ethene, propene, and 1-butene by a midlatitude forest, J. Geophys. Res., 101, 9149-9157, https://doi.org/10.1029/96JD00334, 1996.

Graus, M., Müller, M., and Hansel, A.: High resolution PTR-TOF: quantification and formula confirmation of VOC in real time, J. Am. Soc. Mass Spectr., 21, 1037-1044, 2010.

Guenther, A. B., Zimmerman, P. R., Harley, P. C., Monson, R. K., and Fall, R.: Isoprene and monoterpene emission rate variability: model evaluations and sensitivity analyses, J. Geophys. Res., 98, 12609-12617, 1993.

Guenther, A. B., Jiang, X., Heald, C. L., Sakulyanontvittaya, T., Duhl, T., Emmons, L. K., and Wang, X.: The Model of Emissions of Gases and Aerosols from Nature version 2.1 (MEGAN2.1): an extended and updated framework for modeling biogenic emissions, Geosci. Model Dev., 5, 1471-1492, https://doi.org/10.5194/gmd-5-1471-2012, 2012.

Hakola, H., Rinne, J., and Laurila. T.: The hydrocarbon emission rates of tea-leafed willow (Salix phylicifolia), silver birch (Betula pendula) and European aspen (Populus tremula), Atmos. Environ., 32, 1825-1833, https://doi.org/10.1016/S13522310(97)00482-2, 1998

Hakola, H., Tarvainen, V., Bäck, J., Ranta, H., Bonn, B., Rinne, J., and Kulmala, M.: Seasonal variation of mono- and sesquiterpene emission rates of Scots pine, Biogeosciences, 3, 93-101, https://doi.org/10.5194/bg-3-93-2006, 2006.

Hari, P. and Kulmala, M.: Station for Measuring EcosystemAtmosphere Relations (SMEAR II), Boreal Environ. Res., 10, 315-322, 2005

Harley, R. A, Hannigan, M. P., and Cass, G. R.: Respeciation of organic gas emissions and the detection of excess unburned gasoline in the atmosphere, Environ. Sci. Technol., 26, 2395-2408, 1992.

Hellén, H., Schallhart, S., Praplan, A. P., Petäjä, T., and Hakola, H.: Using in situ GC-MS for analysis of $\mathrm{C}_{2}-\mathrm{C}_{7}$ volatile organic acids in ambient air of a boreal forest site, Atmos. Meas. Tech., 10, 281-289, https://doi.org/10.5194/amt-10-281-2017, 2017.

Holzke, C., Hoffmann, T., Jaeger, L., Koppmann, R., and Zimmer, W.: Diurnal and seasonal variation of monoterpene and sesquiterpene emissions from Scots pine (Pinus sylvestris L.), Atmos. Environ., 40, 3174-3185, 2006.

Horst, T. W.: A simple formula for attenuation of eddy fluxes measured with first order-response scalar sensors, Bound.-Lay. Meteorol., 82, 219-233, 1997.

Hüve, K., Christ, M. M., Kleist, E., Uerlings, R., Niinemets, U., Walter, A., and Wildt, J.: Simultaneous growth and emission measurements demonstrate an interactive control of methanol release by leaf expansion and stomata, J. Exp Bot., 58, 1783-1793, 2007.

Inomata, S., Tanimoto, H., Kameyama, S., Tsunogai, U., Irie, H., Kanaya, Y., and Wang, Z.: Technical Note: Determination of formaldehyde mixing ratios in air with PTR-MS: laboratory experiments and field measurements, Atmos. Chem. Phys., 8, 273 284, https://doi.org/10.5194/acp-8-273-2008, 2008.

Ilvesniemi, H., Pumpanen, J., Duursma, R., Hari, P., Keronen, P., Kolari, P., Kulmala, M., Mammarella, I., Nikinmaa, E., Rannik, U., Pohja, T., Siivola, E., and Vesala, T.: Water balance of a boreal Scots pine forest, Boreal Environ. Res., 15, 375-396, 2010.
Jordan, A., Haidacher, S., Hanel, G., Hartungen, E., Märk, L., Seehauser, H., Schottkowsky, R., Sulzer, P., and Märk, T. D.: A high resolution and high sensitivity proton-transfer-reaction time-offlight mass spectrometer (PTR-TOF-MS), Int. J. Mass Spectrom., 286, 122-128, 2009.

Junninen, H., Ehn, M., Petäjä, T., Luosujärvi, L., Kotiaho, T., Kostiainen, R., Rohner, U., Gonin, M., Fuhrer, K., Kulmala, M., and Worsnop, D. R.: A high-resolution mass spectrometer to measure atmospheric ion composition, Atmos. Meas. Tech., 3, 10391053, https://doi.org/10.5194/amt-3-1039-2010, 2010.

Juráň, S., Pallozzi, E., Guidolotti, G., and Fares, S., and Šigut, L., alfapietra, C., Alivernini, A., Savi, F., Večeřová, K., Křůmal, K., Večeřa, Z., and Urban, O: Fluxes of biogenic volatile organic compounds above temperate Norway spruce forest of the Czech Republic, Agr. Forest Meteorol., 232, 500-513, 2017.

Kaimal, J. C. and Finnigan, J. J.: Atmospheric Boundary Layer Flows: Their Structure and Measurement, Oxford University press, New York, 1994.

Kajos, M. K., Rantala, P., Hill, M., Hellén, H., Aalto, J., Patokoski, J., Taipale, R., Hoerger, C. C., Reimann, S., Ruuskanen, T. M., Rinne, J., and Petäjä, T.: Ambient measurements of aromatic and oxidized VOCs by PTR-MS and GC-MS: intercomparison between four instruments in a boreal forest in Finland, Atmos. Meas. Tech., 8, 4453-4473, https://doi.org/10.5194/amt-8-44532015, 2015.

Karl, T., Guenther, A., Spirig, C., Hansel, A., and Fall, R.: Seasonal variation of biogenic VOC emissions above a mixed hardwood forest in northern Michigan, Geophys. Res. Lett., 30, 1944-8007, 2003.

Kaser, L., Karl, T., Guenther, A., Graus, M., Schnitzhofer, R., Turnipseed, A., Fischer, L., Harley, P., Madronich, M., Gochis, D., Keutsch, F. N., and Hansel, A.: Undisturbed and disturbed above canopy ponderosa pine emissions: PTR-TOF-MS measurements and MEGAN 2.1 model results, Atmos. Chem. Phys., 13, 11935-11947, https://doi.org/10.5194/acp-13-11935-2013, 2013a.

Kaser, L., Karl, T., Schnitzhofer, R., Graus, M., Herdlinger-Blatt, I. S., DiGangi, J. P., Sive, B., Turnipseed, A., Hornbrook, R. S., Zheng, W., Flocke, F. M., Guenther, A., Keutsch, F. N., Apel, E., and Hansel, A.: Comparison of different real time VOC measurement techniques in a ponderosa pine forest, Atmos. Chem. Phys., 13, 2893-2906, https://doi.org/10.5194/acp13-2893-2013, 2013b.

Keenan, R. J., Reams, G. A., Achard, F., de Freitas, J. V., Grainger, A., and Lindquist, E.: Dynamics of global forest area: results from the FAO Global Forest Resources Assessment 2015, Forest Ecol. Manag., 352, 9-20, 2015.

Kormann, R. and Meixner, F. X.: An analytical footprint model for non-neutral stratification, Bounda.-Lay. Meteorol., 99, 207-224, 2001.

Laffineur, Q., Aubinet, M., Schoon, N., Amelynck, C., Müller, J.F., Dewulf, J., Van Langenhove, H., Steppe, K., and Heinesch, B.: Abiotic and biotic control of methanol exchanges in a temperate mixed forest, Atmos. Chem. Phys., 12, 577-590, https://doi.org/10.5194/acp-12-577-2012, 2012.

Langford, B., Acton, W., Ammann, C., Valach, A., and Nemitz, E.: Eddy-covariance data with low signal-to-noise ratio: time-lag determination, uncertainties and limit of detection, Atmos. Meas. 
Tech., 8, 4197-4213, https://doi.org/10.5194/amt-8-4197-2015, 2015.

Makkonen, R., Asmi, A., Kerminen, V.-M., Boy, M., Arneth, A., Hari, P., and Kulmala, M.: Air pollution control and decreasing new particle formation lead to strong climate warming, Atmos. Chem. Phys., 12, 1515-1524, https://doi.org/10.5194/acp12-1515-2012, 2012.

Mammarella I., Launiainen, S., Gronholm, T., Keronen, P., Pumpanen, J., Rannik, Ü., and Vesala, T.: Relative humidity effect on the high frequency attenuation of water vapour flux measured by a closed-path eddy covariance system, J. Atmos. Ocean. Tech., 26, 1856-1866, 2009.

Mammarella, I., Peltola, O., Nordbo, A., Järvi, L., and Rannik, Ü.: Quantifying the uncertainty of eddy covariance fluxes due to the use of different software packages and combinations of processing steps in two contrasting ecosystems, Atmos. Meas. Tech., 9, 4915-4933, https://doi.org/10.5194/amt-9-4915-2016, 2016.

Misztal, P. K., Nemitz, E., Langford, B., Di Marco, C. F., Phillips, G. J., Hewitt, C. N., MacKenzie, A. R., Owen, S. M., Fowler, D., Heal, M. R., and Cape, J. N.: Direct ecosystem fluxes of volatile organic compounds from oil palms in South-East Asia, Atmos. Chem. Phys., 11, 8995-9017, https://doi.org/10.5194/acp11-8995-2011, 2011.

Na, K., Kim, Y. P., Moon, I., and Moon, C.-K.: Chemical composition of major VOC emission sources in the Seoul atmosphere, Chemosphere, 55, 585-594, https://doi.org/10.1016/j.chemosphere.2004.01.010, 2004.

Newbold, T., Hudson, L. N., Hill, S. L. L., Contu, S., Lysenko, I., Senior, R. A., Börger, L., Bennett, D. J., Choimes, A., Collen, B., Day, J., De Palma, A., Díaz, S., Echeverria-Londoño, S., Edgar, M. J., Feldman, A., Garon, M., Harrison, M. L. K., Alhusseini, T., Ingram, D. J., Itescu, Y., Kattge, J., Kemp, V., Kirkpatrick, L., Kleyer, M., Correia, D. L. P., Martin, C. D., Meiri, S., Novosolov, M., Pan, Y., Phillips, H. R. P., Purves, D. W., Robinson, A., Simpson, J., Tuck, S. L., Weiher, E., White, H. J., Ewers, R. M., Mace, G. M., Scharlemann, J. P. W., and Purvis, A.: Global effects of land use on local terrestrial biodiversity, Nature, 520, 45-50, 2015.

Park, J.-H., Goldstein, A. H., Timkovsky, J., Fares, S., Weber, R., Karlik, J., and Holzinger R.: Active AtmosphereEcosystem Exchange of the Vast Majority of Detected Volatile Organic Compounds, Science, 9, 643-647, https://doi.org/10.1126/science.1235053, 2013.

Pirinen, P., Simola, H., Aalto, J., Koukoranta, J.-P., Karlsson, P., Ruuhela, R.: Climatological Statistics of Finland 1981-2010, The Finnish Meteorological Institute, 32-33, 2012.

Potosnak, M. J., LeStourgeon, L., Pallardy, S. G., Hosman, K. P., Gu, L., Karl, T., Geron, C., and Guenther, A. B.: Observed and modeled ecosystem isoprene fluxes from an oak-dominated temperate forest and the influence of drought stress, Atmos. Environ., 84, 314-322, 2014.

Rantala, P., Taipale, R., Aalto, J., Kajos, M. K., Patokoski, J., Ruuskanen, T. M., and Rinne, J.: Continuous flux measurements of VOCs using PTR-MS - reliability and feasibility of disjuncteddy-covariance, surface-layer-gradient, and surface-layer- profile methods, Boreal Environ. Res., 19, 87-107, 2014.

Rantala, P., Aalto, J., Taipale, R., Ruuskanen, T. M., and Rinne, J.: Annual cycle of volatile organic compound exchange between a boreal pine forest and the atmosphere, Biogeosciences, 12, 5753-5770, https://doi.org/10.5194/bg-12-5753-2015, 2015.

Rautiainen, M., Heiskanen, J., and Korhonen, L.: Seasonal changes in canopy leaf area index and MODIS vegetation products for a boreal forest site in central Finland, Boreal Environ. Res., 17, 72-84, 2012.

Rinne, J. and Ammann, C.: Disjunct eddy covariance method, in: Eddy Covariance Handbook, edited by: Aubinet, M., Vesala, T., and Papale, D., Springer, New York, USA, https://doi.org/10.1007/978-94-007-2351-1, 291-307, 2012.

Rinne, J., Hakola, H., Laurila, T., and Rannik, Ü.: Canopy scale monoterpene emissions of Pinus sylvestris dominated forests, Atmos. Environ., 34, 1099-1107, 2000.

Rinne, J., Taipale, R., Markkanen, T., Ruuskanen, T. M., Hellén, H., Kajos, M. K., Vesala, T., and Kulmala, M.: Hydrocarbon fluxes above a Scots pine forest canopy: measurements and modeling, Atmos. Chem. Phys., 7, 3361-3372, https://doi.org/10.5194/acp7-3361-2007, 2007.

Rinne, J., Bäck, J., and Hakola, H.: Biogenic volatile organic compound emissions from the Eurasian taiga: current knowledge and future directions, Boreal Environ. Res, 14, 807-826, 2009.

Rinne, J., Karl, T., and Guenther, A.: Simple, stable, and affordable: Towards long-term ecosystem scale flux measurements of VOCs, Atmos. Environ., 31, 225-227, 2016.

Ruuskanen, T. M., Müller, M., Schnitzhofer, R., Karl, T., Graus, M., Bamberger, I., Hörtnagl, L., Brilli, F., Wohlfahrt, G., and Hansel, A.: Eddy covariance VOC emission and deposition fluxes above grassland using PTR-TOF, Atmos. Chem. Phys., 11, 611-625, https://doi.org/10.5194/acp-11-611-2011, 2011.

Schallhart, S., Rantala, P., Nemitz, E., Taipale, D., Tillmann, R., Mentel, T. F., Loubet, B., Gerosa, G., Finco, A., Rinne, J., and Ruuskanen, T. M.: Characterization of total ecosystem-scale biogenic VOC exchange at a Mediterranean oak-hornbeam forest, Atmos. Chem. Phys., 16, 7171-7194, https://doi.org/10.5194/acp-16-7171-2016, 2016.

Schobesberger, S., Lopez-Hilfiker, F. D., Taipale, D., Millet, D. B., D’Ambro, E. L., Rantala, P., Mammarella, I., Zhou, P., Wolfe, G. M., Lee, B. H., Boy, M., and Thornton, J. A.: High upward fluxes of formic acid from a boreal forest canopy, Geophys. Res. Lett. 43, 9342-9351, https://doi.org/10.1002/2016GL069599, 2016.

Seco, R., Karl, T., Turnipseed, A., Greenberg, J., Guenther, A., Llusia, J., Peñuelas, J., Dicken, U., Rotenberg, E., Kim, S., and Yakir, D.: Springtime ecosystem-scale monoterpene fluxes from Mediterranean pine forests across a precipitation gradient, Agr. Forest Meteorol., 237-238, 150-159, https://doi.org/10.1016/j.agrformet.2017.02.007, 2017.

Spanel, P. and Smith, D.: SIFT studies of the reactions of $\mathrm{H} 3 \mathrm{O}+$, $\mathrm{NO}+$ and $\mathrm{O} 2+$ with a series of alcohols, Int. J. Mass Spectrom., 167, 375-388, https://doi.org/10.1016/S0168-1176(97)00085-2, 1997.

Spracklen, D. V., Bonn, B., and Carslaw K. S.: Boreal forests, aerosols and the impacts on clouds and climate, Philos. T. R. Soc. A, 366, 4613-4626, https://doi.org/10.1098/rsta.2008.0201, 2008.

Taipale, R., Ruuskanen, T. M., and Rinne, J.: Lag time determination in DEC measurements with PTR-MS, Atmos. Meas. Tech., 3, 853-862, https://doi.org/10.5194/amt-3-853-2010, 2010.

Taipale, R., Kajos, M. K., Patokoski, J., Rantala, P., Ruuskanen, T. M., and Rinne, J.: Role of de novo biosynthesis in ecosys- 
tem scale monoterpene emissions from a boreal Scots pine forest, Biogeosciences, 8, 2247-2255, https://doi.org/10.5194/bg-82247-2011, 2011.

Tani, A., Hayward, S., and Hewitt, C.N.: Measurement of monoterpenes and related compounds by proton transfer reaction-mass spectrometry (PTR-MS), Int. J. Mass Spectrom., 223-224, 561578, https://doi.org/10.1016/S1387-3806(02)00880-1, 2003.

Tunved, P., Hansson, H.-C., Kerminen, V.-M., Ström, J., Dal Maso, M., Lihavainen, H., Viisanen, Y., Aalto, P. P., Komppula, M., and Kulmala, M.: High natural aerosol loading over boreal forests, Science, 312, 261-263, 2006.

Vlasenko, A., Macdonald, A. M., Sjostedt, S. J., and Abbatt, J. P. D.: Formaldehyde measurements by Proton transfer reaction Mass Spectrometry (PTR-MS): correction for humidity effects, Atmos. Meas. Tech., 3, 1055-1062, https://doi.org/10.5194/amt3-1055-2010, 2010.
Wohlfahrt, G., Amelynck, C., Ammann, C., Arneth, A., Bamberger, I., Goldstein, A. H., Gu, L., Guenther, A., Hansel, A., Heinesch, B., Holst, T., Hörtnagl, L., Karl, T., Laffineur, Q., Neftel, A., McKinney, K., Munger, J. W., Pallardy, S. G., Schade, G. W., Seco, R., and Schoon, N.: An ecosystem-scale perspective of the net land methanol flux: synthesis of micrometeorological flux measurements, Atmos. Chem. Phys., 15, 7413-7427, https://doi.org/10.5194/acp-15-7413-2015, 2015. 